\title{
PROPRIEDADE INDUSTRIAL E INSTITUIÇÕES NA PRIMEIRA REPÚBLICA
}

\section{INDUSTRIAL PROPERTY AND INSTITUTIONS IN THE FIRST REPUBLIC}

\author{
LEANDRO MiRANDA MALAVOTA ${ }^{1}$
}

RESUMO: O artigo propõe uma reflexão sobre o arcabouço jurídico-institucional de regulação sobre a propriedade industrial no Brasil durante a Primeira República (1889-1930). Após um breve balanço das principais características dos sistemas de patentes e marcas durante o período imperial, analisamos o modelo vigente durante as três primeiras décadas da República, atentando para os seus aspectos institucionais, os conceitos jurídicos que o sustentavam, bem como as funções econômicas por ele cumpridas. Identificamos nesta primeira fase um claro apartamento jurídico e administrativo entre patentes e marcas, o estabelecimento de um regime de livre concessão e a inexistência de uma instituição oficial especializada e exclusiva para o tratamento dos assuntos referentes à propriedade industrial. Os anos 1920 marcariam uma inflexão nessa trajetória, inaugurando-se um regime de novo tipo, pautado na unificação administrativa e na adoção do exame prévio. Notamos ainda que a nova estrutura institucional já nasce com evidentes limitações, mostrando-se desde cedo incapaz de atender à crescente demanda dos setores produtivos por seus serviços. A reforma dos anos 1920 não teria alcançado os objetivos vislumbrados e novas intervenções seriam efetuadas ao irromper da Era da Vargas

Palavras-Chave: Propriedade Industrial; Patentes; Marcas; Desenvolvimento Econômico.

\footnotetext{
${ }^{1}$ Graduação em História pela Universidade Federal do Rio de Janeiro (2003), mestrado em História Social pela Universidade Federal do Rio de Janeiro (2006) e doutorado em História pela Universidade Federal Fluminense (2011). Tem experiência de docência e pesquisa nas áreas de História do Brasil (Império e República) e História Econômica, com ênfase nos seguintes temas: propriedade intelectual, inovação, transferência de tecnologia e desenvolvimento econômico. Atualmente é analista do Instituto Brasileiro de Geografia e Estatística (IBGE), desenvolvendo atividades nos campos da memória empresarial, tratamento de documentação histórica e disseminação de informações, com base nas diretrizes teórico-metodológicas da História Pública. É um dos fundadores da Rede Proprietas, onde desenvolve pesquisas sobre a temática da apropriação de bens tecnológicos, tendo como recorte cronológico os séculos XIX e XX. Pesquisador associado ao Instituto Nacional de Ciência e Tecnologia (INCT) História Social das Propriedades e Direitos de Acesso. Pesquisador associado ao Núcleo de Pesquisa Propriedade e suas Múltiplas Dimensões (NUPEP).
} 
ABSTRACT: This paper proposes a reflection on the brazilian industrial property system during the First Republic (1889-1930). After brief comments on the main aspects concerning patents and trademarks during the imperial period, we analyze the legal-institutional model in force in the first three decades of the Republic, considering its economic impacts. In a first period (1889-1923), we identify a legal and administrative separation between patents and trademarks, the estabilishment of registration systems and the absence of specialized agencies. The Twenties marked a turning point in this framework, inaugurating a new type of regime, based on the administrative unification and the adoption of an examination system. We also note that the new institutional structure was born with evident limitations, showing itself unable to meet the growing demand for patent and trademark services. The reform of the 1920s did not achieve its objectives and new interventions would be carried out during the Vargas Era.

KEYWORDS: Industrial Property; Patents, Trademarks; Economic Growth.

\section{INTRODUÇÃO}

De forma genérica, a propriedade intelectual pode ser definida como um conjunto de direitos que incidem sobre determinadas criações do intelecto humano. Segundo a Organização Mundial da Propriedade Intelectual (OMPI), órgão autônomo das Nações Unidas responsável pela promoção de sua proteção em nível internacional mediante a cooperação entre Estados, a propriedade intelectual constitui a soma dos direitos relativos aos seguintes objetos: obras artísticas, científicas e literárias; invenções; interpretações e execuções de produções artísticas; fonogramas e emissões de radiodifusão; desenhos e modelos industriais; marcas de indústria, comércio e serviços; firmas e nomes comerciais; indicações geográficas; proteção contra a concorrência desleal (WIPO, 2004). Barbosa (2010, p. 7) adverte que esse rol não é exaustivo, podendo incorporar "todos os outros direitos inerentes à atividade intelectual nos domínios industrial, científico, literário e artístico". A literatura jurídica também assinala que a propriedade intelectual constitui um poder restrito exercido por uma pessoa sobre um bem imaterial, posto que condicionado a parâmetros pré-estabelecidos de conduta, ou seja, disciplinado por um conjunto específico de regras (DI BLASI, GARCIA E MENDES, 1998).

Partindo-se de tais definições, os direitos de propriedade intelectual são divididos em dois grandes campos: o primeiro compreendendo a proteção, sob os aspectos moral e patrimonial, do criador de obra artística, literária e científica, materializada no estatuto do direito de autor; o segundo, por sua vez, envolvendo a proteção de bens intangíveis industrialmente aplicáveis, consubstanciado no estatuto da propriedade industrial. Cabe ressaltar que a propriedade intelectual também engloba certos tipos de objetos sui generis, como a proteção a cultivares e à topografia de circuitos integrados. 
Ao contrário do que pode ser observado em outros países, não são abundantes no Brasil os estudos históricos acerca dos temas e objetos relacionados ao campo da propriedade industrial. Grande parte das discussões existentes é encontrada em obras jurídicas, geralmente servindo como passo preliminar a análises teóricodoutrinárias, conforme observado em Bailly (1915), Cerqueira (1982), Domingues, (1984), entre outros. Contudo, ainda que escassos, alguns trabalhos propõem uma investigação histórica mais profunda e metódica, alicerçada na exploração de fontes primárias de distintas naturezas. Uma referência fundamental encontramos em Rodrigues (1973), primeira pesquisa de fôlego sobre a história do sistema de patentes no Brasil. Ao discorrer sobre as iniciativas voltadas ao aperfeiçoamento de bens e processos de produção ao longo de quase quatro séculos, efetua um rigoroso exame do arcabouço jurídico de proteção e incentivo à atividade inventiva inaugurado em Portugal e seus domínios durante o período joanino. ${ }^{2}$ Além de uma minuciosa análise de aspectos relacionados às patentes no Brasil ao longo do Oitocentos, também efetua um levantamento dos privilégios concedidos entre 1809 e 1892, constituindo talvez a primeira iniciativa no país de sistematização de informações contidas em documentos de patentes para fins de estudos históricos.

Levou alguns anos para que novos trabalhos surgissem. Por ocasião das comemorações do centenário da Convenção da União de Paris, primeiro tratado internacional voltado à regulação da propriedade industrial, Cruz Filho (1982) desenvolveu uma investigação sobre o processo de adesão do Brasil ao acordo, considerando seus aspectos políticos, econômicos e diplomáticos. Almeida (2001) aprofundaria a exploração da temática, dedicando um capítulo de sua extensa pesquisa sobre a formação da diplomacia econômica no período imperial à discussão sobre a inserção do Brasil no sistema internacional de patentes. Com base no levantamento de Rodrigues (1973), Cruz e Tavares (1986) efetuaram um exame dos privilégios patentários concedidos sob a Lei de Patentes de 1830, promovendo a partir desses dados uma análise da economia do Império. Cabelo e Póvoa (2016) propuseram um estudo econômico semelhante sobre o mesmo período, porém, apoiados em um corpus documental mais extenso e completo, expandiram os resultados obtidos três décadas antes. Carvalho (2009) escolheu como objeto o Alvará de 28 de abril de 1809 - primeiro ato a regular a concessão de privilégios a inventores em Portugal e suas colônias - sustentando a hipótese de que sua promulgação teria servido ao atendimento de interesses econômicos ingleses. Groff (2014), por sua vez, propôs uma análise do desenvolvimento da legislação patentária brasileira do século XIX aos dias atuais, argumentando que, a despeito de sua longevidade, ela não promoveu uma real estrutura de proteção aos direitos

\footnotetext{
2 Assim como outras monarquias europeias, a coroa portuguesa adotou pelo menos desde o Quatrocentos a prática de distribuir privilégios e outras mercês a inventores e introdutores de novos bens ou processos de produção, como recompensa por serviços prestados. Contudo, somente no início do século XIX a concessão de tais privilégios foi regulamentada em lei, por meio do Alvará do Príncipe Regente de 28 de abril de 1809.
} 
do inventor. Já em um estudo sobre os fundamentos filosóficos, cognitivos e semióticos do sistema de patentes, Cruz Filho (2015) esboçou um balanço das políticas de propriedade industrial e transferência de tecnologia implementadas no Brasil na segunda metade do século XX, sintetizando e aprofundando reflexões dispersas em trabalhos como os de Biato, Guimarães e Figueiredo (1973), Barbosa (1981) e Cardozo (1990).

O que se observa na produção supracitada é a predominância de estudos sobre um dos objetos de propriedade industrial - as patentes de invenção - em detrimento dos demais e a concentração das atenções em seus aspectos legais e econômicos. Poucas são as reflexões acerca de sua dimensão institucional. Em trabalho anterior, propusemo-nos a enfrentar essa questão, em meio a um estudo mais amplo sobre o sistema patentário brasileiro, com recorte cronológico fixado no interstício 1809-1882 (MALAVOTA, 2011). Acreditamos, contudo, que ainda há muitas lacunas a serem preenchidas. Nossa proposta no presente artigo é justamente dar continuidade a esse esforço, promovendo os primeiros esboços de um estudo sobre as instituições oficiais de propriedade industrial no Brasil. Para isso, propomos a escolha de um novo recorte temporal - o período compreendido entre 1889 e 1930 - , a exploração de um leque distinto de fontes primárias e o enfrentamento de novos problemas. Objetivamos, em suma, observar as transformações ocorridas no arcabouço institucional de propriedade industrial durante a Primeira República, atentando para suas principais características, funções, debilidades e formas de interação com a sociedade, atentando sempre que possível para as relações estabelecidas entre os agentes institucionais e os usuários desses serviços

\section{PATENTES, Leis E instituições NA COlÔNiA E NO IMPÉRIO: BREVE PANORAMA HISTÓRICO}

Conforme anteriormente comentado, a prática de concessão de privilégios e outras mercês a inventores e introdutores foi aplicada em Portugal desde o início da Idade Moderna, reproduzindo o que ocorria em boa parte da Europa. Os exclusivos eram ratificados por meio de cartas-patentes, aplicáveis geralmente no Reino, mas também extensivas aos súditos estabelecidos nos domínios d'além-mar. No caso das terras do Brasil, a primeira patente conhecida data de 1707, concedida ao padre Bartolomeu Lourenço de Gusmão pela invenção de um novo sistema de bombas hidráulicas (CRUZ FILHO, 1985). Considerando a escassez, dispersão e conservação da documentação de época, é difícil determinar o número exato de privilégios concedidos a inventores e introdutores no Brasil ao longo do século XVIII, embora baseados na pesquisa de Santana (1984) possamos estimar que entre meados do Setecentos e a primeira década do Oitocentos eles tenham alcançado pouco mais de uma dezena. $3 \mathrm{O}$ que se tem de concreto sobre o período é que a

\footnotetext{
${ }^{3}$ Em levantamento efetuado junto à documentação depositada no Arquivo Nacional Torre do Tombo, Santana (1984) identificou 152 pedidos de patentes examinados pela Junta do Comércio
} 
concessão de patentes constituía uma prerrogativa régia, uma mercê concedida como recompensa por serviços prestados ou por manifesto interesse do monarca, recorrendo este último ao suporte da Real Junta do Comércio, instância consultora chamada a opinar sobre a conveniência das concessões por meio de pareceres. 4

As Guerras Napoleônicas e a consequente transmigração da Corte para o Brasil concorreram para uma mudança significativa no cenário até então descrito. Instalada em suas possessões na América, a Coroa bragantina viu-se diante do desafio de transformar um espaço até então periférico em novo centro do Império português. Dentre as inúmeras medidas políticas, administrativas e econômicas tomadas pela governação joanina, destacamos o Alvará com força de lei de 28 de abril de 1809, que, entre diversas providências voltadas ao estímulo das atividades produtivas nas possessões portuguesas, promoveu a regulamentação da concessão de privilégios a inventores e introdutores de novas indústrias. Além da determinação de requisitos, prazos, aplicações e funções dos exclusivos, o estatuto ratificou o papel da Real Junta do Comércio como instância interveniente nos processos de concessão de patentes, na condição de consultora da Coroa. No caso dos pedidos de patentes efetuados no Brasil, as consultas passaram a ser remetidas à Real Junta de Comércio, Agricultura, Fábricas e Navegação do Estado do Brasil e seus Domínios Ultramarinos, tribunal criado em 1808 no Rio de Janeiro, à imagem e semelhança do congênere lisboeta, como parte do processo de reprodução da aparelhagem burocrática do Estado português na nova capital do Império (ANDRADE, 1980).

A emancipação política ocorrida em 1822 em pouco mudou o quadro da proteção patentária no Brasil. Embora o direito de propriedade do inventor sobre suas obras tenha sido garantido pela Constituição de 1824, a primeira Lei de Patentes do Império, promulgada em 1830, promoveu a sobreposição de conceitos liberais e de Antigo Regime, engendrando um regime jurídico de natureza híbrida. A concessão de patentes permaneceu como uma prerrogativa do monarca, que poderia recorrer às instâncias que considerasse adequadas para respaldar suas decisões, prevalecendo a concepção de um Estado provedor de um privilégio por meio da graça régia, não mero garantidor de um direito inerente ao indivíduo. Ainda que a letra da lei não estabelecesse literalmente a obrigação do exame prévio,

de Lisboa entre 1757 e 1830. No interstício 1757-1808 podemos notar um total de 90 consultas, sendo 11 delas referentes a invenções desenvolvidas no Brasil. O autor alerta, no entanto, para uma lacuna identificada no período 1778-1788, no qual as atividades industriais em Portugal foram colocadas sob a supervisão de outra instituição, a Junta da Administração das Fábricas do Reino e Águas Livres.

${ }^{4}$ A Junta do Comércio Deste Reino e Seus Domínios foi criada em 1755, como instância de suporte a decisões da Coroa nos campos comercial e industrial. Dentre as suas distintas atribuições, destacamos a apreciação dos diversos tipos de consultas e requerimentos encaminhados ao monarca por mercadores, artesãos e proprietários de fábricas, incluídos os pedidos de patentes. Em 1788 a instituição foi alçada à categoria de Tribunal Régio, recebendo o título de Real Junta do Comércio, Agricultura, Fábricas e Navegação deste Reino e seus Domínios. 
a prática foi mantida. A concessão das patentes era condicionada à novidade e ao mérito da invenção, aferidos por meio de uma análise efetuada por instância especializada, provocada por consulta do Imperador ou de outras autoridades por delegação de competência. Reconhecida desde os tempos joaninos como referência no assunto, a Junta do Comércio manteve-se como detentora do argumento de autoridade até meados do século, sendo geralmente a instância acionada pela Coroa para o exame dos pedidos de patentes. Somente com o progressivo definhamento do tribunal, já nos anos 1840, e sua definitiva dissolução, em 1850, outras instituições passaram a ser usualmente chamadas a prestar serviço ao governo, assessorando-o nas decisões. Destacamos entre elas a Seção do Negócios do Império do Conselho de Estado 5 e a Sociedade Auxiliadora da Indústria Nacional (SAIN). 6

Percebemos, pois, que durante a maior parte do período imperial o arcabouço institucional que sustentava o sistema brasileiro de patentes mostrou-se extremamente simples. Os interessados formulavam um pedido ao monarca, composto por uma minuciosa descrição da invenção, acompanhada por planos e desenhos. Uma via dessa documentação era encaminhada ao Arquivo Público - que mantinha o material em sigilo até o fim do privilégio - e outra à Secretaria de Estado dos Negócios do Império, que atuava por delegação de competência do Imperador. A partir dos anos 1860, após uma reforma organizacional no primeiro escalão do governo, essa delegação foi repassada à recém-criada Secretaria de Estado dos Negócios da Agricultura, Comércio e Obras Públicas.7 A despeito da existência de órgãos oficiais incumbidos do tratamento dos processos de patentes, as concessões

${ }^{5}$ Criado em 1823, o Conselho de Estado tinha como incumbência a prestação de auxílio ao monarca na administração da coisa pública, arbitragem de conflitos sociais e a definição de padrões para o exercício do Poder Moderador. Extinto em 1834 e recomposto em 1841, acumulou rapidamente força e prestígio no Segundo Reinado, assumindo funções cada vez mais complexas, como a guarda da ordem constitucional, determinação dos limites de jurisdição dos diferentes poderes, a análise da inteligência das leis, etc. O chamado $2^{\circ}$ Conselho de Estado (1842-1889) foi dividido em quatro diferentes seções: Fazenda; Justiça e Estrangeiros; Negócios Eclesiásticos; Negócios do Império. Coube justamente a esta última pronunciar-se, sob consulta do Imperador, quanto à conveniência da concessão de patentes, ação concentrada nos anos 1840 e 1850 (RODRIGUES, 1978; CARVALHO, 2007; MARTINS, 2007).

${ }^{6}$ Criada em 1825 e efetivamente instalada dois anos depois, a SAIN era uma associação civil de assistência aos produtores nacionais e de fomento às chamadas artes úteis, tendo como missão promover a racionalização, mecanização e aprimoramento das atividades produtivas do país particularmente a agricultura, carro-chefe da economia. Tratava-se de uma entidade de direito privado, embora estreitamente vinculada à jurisdição governamental, fosse pelos controles exercidos sobre seus estatutos, fosse pelas subvenções oficiais que nutriam seus cofres. A partir de meados do Oitocentos a SAIN se tornou a principal instituição interveniente nos processos de concessão de patentes (SILVA, 1979; MALAVOTA, 2020).

${ }^{7}$ Nesse ministério, os serviços relacionados às patentes de invenção estiveram primeiramente vinculados a um de seus órgãos de direção superior, a Diretoria Central. Após uma reorganização administrativa ocorrida em 1873, eles foram repassados para a 2 Seção da Diretoria do Comércio. 
mantiveram-se durante todo o período baseadas nos pareceres das instituições intervenientes, públicas ou privadas. Em nenhum momento as instâncias oficiais se envolveram diretamente no exame dos pedidos tampouco dispuseram de poder decisório.

Nas duas últimas décadas do Segundo Reinado transformações importantes foram sentidas no cenário econômico. No setor agroexportador, as pressões sobre os custos de produção impeliam os proprietários rurais a lançar mão das soluções tecnológicas progressivamente disponibilizadas nos países industriais, em um contexto de franca expansão do crédito e do comércio internacional. Paralelamente, um incipiente setor secundário também começava a ganhar corpo, elevando a demanda por máquinas e equipamentos aplicáveis à fabricação de bens de consumo não duráveis. A tecnologia ganhava importância enquanto fator de produção, conferindo nova funcionalidade ao sistema de patentes. Se entre 1830 e 1871 foram concedidos no país 212 privilégios, entre invenções e introduções, para o período 1872-1882 esse número se elevou para 598 (CARRARA JR., MEIRELLES, 1996, p. 873-906). Produtores, negociantes e inventores passavam a pressionar o governo em prol de mudanças na legislação patentária, considerada obsoleta e inadequada às necessidades de uma economia em vias de modernização. Disseminou-se entre distintos segmentos sociais a crença de que a adoção dos padrões de proteção seguidos pelas principais potências econômicas do período garantiria a facilitação do acesso aos novos bens e processos de produção que surgiam em profusão no contexto da Segunda Revolução Industrial. Essa convergência de fatores internos e externos culminaria com uma reforma da legislação patentária em 1882 (BRASIL, 1882) e com a adesão do país, no ano seguinte, à Convenção da União de Paris para a Proteção da Propriedade Industrial. 8

Não entraremos em detalhes sobre os ditames da Lei de Patentes de 1882, matéria já bastante discutida pela literatura especializada. 9 Citaremos somente alguns de seus mais evidentes princípios e determinações, elementos importantes para a discussão que proporemos a seguir. Uma ruptura em relação à legislação anterior foi a abolição do exame prévio, exceto para os pedidos que envolvessem produtos químicos, farmacêuticos ou alimentícios. Notamos, portanto, que foi adotado um regime de livre concessão (registration system), limitando-se a análise

\footnotetext{
${ }^{8}$ Conforme anteriormente comentado, a Convenção da União de Paris constituiu o primeiro tratado multilateral sobre aspectos relacionados a patentes, marcas, desenhos industriais e indicações geográficas, estabelecendo padrões mínimos de proteção a serem seguidos por todos os países signatários. O Brasil foi um dos 11 signatários originais do Acordo de Paris, juntamente com Bélgica, El Salvador, Espanha, França, Guatemala, Itália, Países Baixos, Portugal, Sérvia e Suíça. Em 1884, por ocasião da troca de ratificações entre os países que compunham a convenção, uniram-se a esse grupo Grã-Bretanha, Tunísia e Equador.

${ }_{9}^{9}$ Citamos como exemplos as análises desenvolvidas por Bailly (1915), Groff (2014) e Malavota (2011).
} 
dos pedidos a alguns objetos específicos. Já incorporando algumas das exigências estabelecidas pela CUP, o estatuto equiparava o tratamento dispensado a nacionais e estrangeiros. Os requisitos estabelecidos para patenteamento eram a novidade da invenção e a aplicabilidade industrial, enquanto a insuficiência descritiva constituía motivo para anulação de um privilégio já concedido.10 O prazo de validade dos privilégios era de 15 anos, a contar da data do decreto de concessão. A proteção também se estendia aos aperfeiçoamentos efetuados a bens já existentes, ainda que limitada ao prazo de vigência da patente original. A lei também previa mecanismos para cessão ou transmissão de direitos de propriedade, assim como a tipificação e criminalização das infrações a esses mesmos direitos. Oposições e litígios foram lançados ao âmbito do judiciário.

Cabe ainda nesse breve balanço sobre a propriedade industrial no Império do Brasil alguns comentários a respeito das marcas de indústria, comércio e serviços. O primeiro marco legal sobre a matéria surgiu em 1875, após um litígio judicial que provocou forte impacto sobre a opinião pública.11 A controvérsia teve início no ano anterior, quando a empresa baiana Meuron \& Companhia, produtora do Rapé Arêa Preta, moveu uma ação contra Moreira \& Companhia, concorrente pernambucana produtora do Rapé Arêa Fina. Alegava-se que a acusada vinha apondo a seu produto nome e embalagem semelhantes aos já utilizados pela parte autora, levando os consumidores a confusão e causando prejuízos à reclamante. $\mathrm{O}$ fato do Tribunal da Relação da Bahia ter arquivado o processo, sob a alegação de que a usurpação de marca não constituía crime previsto em lei, acabou gerando fortes protestos dos comerciantes da praça da Bahia, ganhando o caso destaque na imprensa local. Diante da situação, o Legislativo foi provocado a tomar providências e após um curto período de estudos foi proposto um projeto de lei para regulação do registro de marcas no país, tendo como base a legislação francesa.

A Lei de Marcas de 1875 estabeleceu, entre outras coisas, o direito de qualquer cidadão identificar seus produtos através do uso de sinais distintivos, a restrição do uso dessas marcas ao próprio produtor, o registro prévio como fator gerador do direito e a repressão aos crimes contra a propriedade das marcas (BRASIL, 1875). No que concerne ao seu tratamento institucional, ficou estabelecido que os pedidos de registros fossem efetuados nos Tribunais ou Conservatórias do Comércio de

\footnotetext{
${ }^{10} \mathrm{O}$ princípio da novidade consistia na ausência de anterioridade no emprego do bem ou processo no país ou fora dele, o que incluía também a sua descrição e publicação por meios que pudessem concorrer para o seu emprego, salvaguardando-se o período de prioridade unionista. Já o princípio da aplicabilidade industrial exigia que o objeto fosse passível de aplicação em qualquer tipo de indústria, excluindo-se concepções abstratas e esquemas de negócios.

${ }^{11}$ Uma interessante narrativa do caso foi efetuada pelo jovem advogado Rui Barbosa, representante da parte acusadora. Sobre o assunto ver Barbosa (1984, p. 25-122).
} 
cada província, onde ficariam depositados os modelos das marcas. 12 Com a reforma ocorrida naquele mesmo ano, os Tribunais e as Conservatórias do Comércio foram extintos e transformados, respectivamente, nas Juntas e Inspetorias Comerciais, que a partir de então passaram a executar o serviço da administração comercial nas províncias, inclusive o registro de marcas. Eram sete as Juntas Comerciais em funcionamento no Império - Rio de Janeiro, Belém, São Luiz, Fortaleza, Recife, Salvador e Porto Alegre - , abrangendo cada uma delas uma dada jurisdição territorial. As Inspetorias Comerciais foram instaladas nas províncias onde não existiam Juntas Comerciais, sendo vinculadas às Juntas que abrangiam a sua região. O modelo foi mantido até o final do Império, ratificado em nova Lei de Marcas promulgada em 1887.

\section{O CONTEXTO dA PRIMEIRA República}

Ao longo das três primeiras décadas do regime republicano o arcabouço jurídico-institucional construído ao final do Império sofreu poucas alterações. No campo das patentes, os ditames da Lei de 1882 continuaram vigendo, com pequenos ajustes determinados por decretos, atos administrativos ou interpretações dos tribunais. ${ }^{13}$. Qualquer indivíduo ou sociedade empresarial, independentemente de nacionalidade ou residência, poderia solicitar uma patente de invenção, encaminhando o pedido ao órgão oficial competente. $\mathrm{O}$ interessado deveria depositar em duplicata uma memória, escrita em português, descrevendo com precisão e clareza a invenção, suas características, seus objetivos e modo de funcionamento. A memória deveria ser acompanhada por desenhos, planos, modelos, amostras e quaisquer outros meios capazes de transmitir informações acerca da invenção, de modo que qualquer pessoa conhecedora da matéria pudesse replicá-la. A descrição também deveria deixar claros os avanços que a invenção apresentava em relação ao estado da técnica e quais as exatas reivindicações do titular. Os planos e desenhos deveriam ser entregues em envelope à parte, lacrado e padronizado conforme a lei.

O Ministério da Agricultura, que ao longo da Primeira República recebeu diferentes denominações e submeteu-se a vários arranjos, ${ }^{14}$ permaneceu como

${ }^{12} \mathrm{O}$ Código Comercial de 1850 criou os Tribunais e as Juntas do Comércio. Os primeiros, que sucederam a Junta do Comércio do Rio de Janeiro, tinham funções judicantes e administrativas na área comercial, tendo inicialmente representações instaladas na Corte, na Bahia e em Pernambuco. Já as últimas foram instaladas nas províncias que não dispunham de Tribunais do Comércio e desempenhavam funções administrativas, sendo rebatizadas em 1855 como Conservatórias do Comércio. Nos anos 1870 os Tribunais do Comércio perderam as suas funções judicantes, transferidas para as Relações.

13 Um levantamento dos principais decretos, portarias avisos e decisões jurisprudenciais envolvendo as patentes de invenção no período 1882-1915 é reproduzido em Bailly (1915).

${ }^{14}$ Embora o Governo Provisório de Deodoro da Fonseca (1889-1891) tenha efetuado de pronto algumas mudanças organizacionais no ministério, boa parte da estrutura construída no Império 
instância governamental responsável pela prestação dos serviços patentários. Entre 1891 e 1905 essa atividade foi atribuída à 1ª Seção da Diretoria Geral da Indústria, em cujo âmbito eram administrados temas relacionados à agricultura, indústria fabril, comércio, correios e colonização. Cabia à repartição, primeiramente, efetuar o acolhimento dos pedidos e o registro de informações sobre o requerente (nome, nacionalidade, profissão, domicílio etc.) e a invenção (título, função e aplicação). $O$ pedido passava apenas por um exame formal e caso todas as exigências legais fossem cumpridas a patente era imediatamente concedida. Assim como a legislação que a precedeu, a Lei de 1882 estabeleceu o Arquivo Público como repositório de todo o material anexado ao processo. Contudo, a partir de 1891, a própria repartição responsável pelos serviços patentários passou a exercer essa função, dada a inadequação do Arquivo Público para a guarda de modelos, amostras e outros objetos que não fossem documentos em papel (RELATÓRIO, 1891). Finalmente, após nova reorganização do ministério em 1906, todas essas atividades passaram à responsabilidade da $1^{a}$ Seção da recém-criada Diretoria Geral da Indústria e Comércio, órgão de direção superior do então renomeado Ministério da Agricultura Indústria e Comércio.

Como se pode notar, os serviços patentários inseriam-se entre as diversas atividades desempenhadas pelas repartições ministeriais a que foram legalmente atribuídos, apresentando feições tipicamente cartoriais. Efetuavam-se fundamentalmente os registros administrativos, a aferição de formalidades, o recolhimento de taxas e os procedimentos para publicação e emissão da cartapatente. Somente os casos em que a lei previa a realização de exame prévio exigiam outro tipo de intervenção que, entretanto, permaneceu dependente de atuação de consultores externos, assim como no regime da lei anterior. À repartição oficial não foi delegada competência técnica para a realização dos exames prévios, recorrendose ao auxílio de instituições intervenientes. A diferença para o período imperial é que agora os pareceres eram solicitados exclusivamente a órgãos públicos, conforme determinado pelo regulamento da Lei de $1882 .{ }^{15}$

No que concerne às marcas, de maneira análoga, o tratamento dos pedidos de registros foi mantido nas Juntas Comerciais, um serviço sob a responsabilidade dos

foi mantida. Em 1891 o órgão passou a ser denominado Ministério da Indústria, Viação e Obras Públicas, sendo sua cúpula administrativa composta pelo Gabinete do ministro e quatro Diretorias-Gerais (Indústria, Contabilidade, Viação e Obras Públicas). Em 1906 o órgão foi submetido a outra grande reforma e passou a ser denominado Ministério da Agricultura, Indústria e Comércio, efetivamente instalado em 1909 e mantido até 1930.

${ }^{15}$ O Decreto n. ${ }^{\circ}$ 8.820, de 30 de dezembro de 1882, estabeleceu o regulamento da Lei n. ${ }^{\circ} 3.129$ de 14 de outubro de 1882. O ato atribuía competência para a realização do exame prévio ao Procurador da Coroa (para o caso de invenções que parecessem contrárias à moral ou à segurança pública), à Junta Central de Higiene Pública, às Escolas Politécnica, Militar, de Marinha e à Faculdade de Medicina da Corte. Em casos excepcionais, quaisquer outras instituições públicas poderiam ser chamadas a se pronunciar pelo Ministro da Agricultura, conforme a natureza dos objetos reivindicados nos pedidos de patente. 
poderes estaduais. A partir de 1904, por força do Decreto n. ${ }^{\text {o }}$ 1.236, os titulares passaram a ser obrigados a depositar os modelos de suas marcas na Junta Comercial do Distrito Federal, sem que esta tivesse, no entanto, qualquer poder para anular os registros efetuados nos estados em face de eventuais irregularidades. A mesma repartição da capital também era incumbida de receber os pedidos de registros feitos por titulares estrangeiros no Brasil e os pedidos internacionais encaminhados pelos Bureaux Internacionaux Reunis Pour la Proctetion de la Propriété Intelectuelle (BIRPI), com sede em Berna, em consequência da adesão do Brasil ao Acordo de Madri, tratado que instituiu um sistema internacional de registro de marcas. ${ }^{16}$ Durante a maior parte da Primeira República, enfim, o sistema marcário brasileiro manteve-se descentralizado e administrativamente apartado do sistema de patentes.

Embora a reforma ocorrida em 1882 tivesse o objetivo de contemplar os interesses de produtores nacionais e estrangeiros, buscando agilizar tanto $\mathrm{o}$ processo de concessão dos exclusivos quanto o acesso e a divulgação de informação tecnológica patenteada, o novo estatuto não ficou imune a críticas. Representantes da indústria de pronto condenaram a não exigência da exploração local obrigatória, o que, em sua opinião, tornava o país refém da importação de bens essenciais e prejudicava os interesses dos produtores nacionais, excluídos do mercado por força das patentes estrangeiras. ${ }^{17}$ Já expoentes do campo liberal saudavam os avanços alcançados pela nova legislação, embora frisassem que as restrições impostas aos produtos químicos, farmacêuticos e alimentícios criavam desestímulos ao patenteamento - e consequentemente aos investimentos - nesses importantes segmentos industriais. Em tal interpretação, o exame prévio, ainda que restrito a poucos objetos, era tomado como uma intervenção indevida do Estado sobre um direito individual de propriedade, além de uma medida burocratizante, contrária

\footnotetext{
${ }^{16} \mathrm{O}$ Acordo de Madri constitui um tratado firmado no âmbito da Convenção da União de Paris em 1891, tendo como objeto o depósito internacional de marcas. Por ele, um único pedido de registro feito através do BIRPI (atualmente OMPI) gera pedidos nos países escolhidos pelo titular, desde que signatários do tratado. Trata-se, portanto, de um mecanismo voltado à facilitação dos registros de marcas em nível internacional, gerando direitos e obrigações aos países signatários. O Brasil aderiu ao tratado em 30 de outubro de 1896 (UNION, 1901), sendo a sua aplicação iniciada no ano seguinte, após a devida regulamentação da matéria pelo Decreto n. 2.747, de 17 de dezembro daquele mesmo ano.

${ }^{17} \mathrm{O}$ princípio da exploração local obrigatória era adotado por países como a França e ÁustriaHungria, exigindo-se que, para que um titular pudesse gozar das prerrogativas oferecidas pela patente o mesmo estabelecesse uma unidade produtiva em seu território dentro de um determinado prazo, não se aceitando a importação como prova da exploração da invenção. Um dos maiores defensores da inclusão desse princípio na legislação nacional foi o deputado mineiro Antônio Felício dos Santos, industrial da área têxtil e um dos fundadores da Associação Industrial na última década do império.
} 
ao espírito da lei. ${ }^{18}$ Argumentava-se ainda que, na maioria dos casos, a submissão de certos pedidos a exame prévio mostrava-se inútil, posto que a patenteabilidade do objeto não podia ser confundida com a sua exploração (BAILLY, 1915). Consequentemente, a concessão de uma patente não traria prejuízo nenhum à sociedade mesmo que seu objeto fosse considerado ilícito, uma vez que, proibidos o uso ou a comercialização, o exclusivo constituiria letra morta.

Outro mecanismo importante inaugurado pela Lei de 1882 que se tornou alvo de críticas imediatas foi a validação no país de patentes concedidas no exterior. Estabelecia-se nesse caso uma espécie de rito sumário no processo de concessão, bastando ao estrangeiro que desejasse obter uma patente no Brasil comprovar ter obtido privilégio para o mesmo objeto em seu país de origem, desde que não fosse caracterizado qualquer desacordo com a legislação nacional. Entretanto, o mecanismo apresentou uma evidente contradição com o requisito da novidade, permitindo que patentes fossem concedidas a objetos em domínio público. $\mathrm{O}$ problema foi seguidamente apontado nos relatórios apresentados nos anos 1880 pela pasta da Agricultura, Comércio e Obras Públicas à Assembleia Geral, até que o Conselho de Estado foi chamado a se pronunciar sobre o assunto. Como resultado, em 1887 o governo baixou um decreto interpretando a validação das patentes estrangeiras como uma exceção ao princípio da novidade, porém estabelecendo um prazo máximo de sete meses, a contar da concessão da patente original, para que a mesma fosse requerida pelo titular (BRASIL, 1887). Essa questão foi, portanto, rapidamente resolvida, não se estendendo a controvérsia aos anos seguintes.

Um ponto bastante discutido nas duas primeiras décadas republicanas foi a necessidade de ajustes no sistema de livre concessão. $O$ que seguidamente se observa nos relatórios ministeriais são queixas quanto aos efeitos causados por patentes ilegais, fosse por ausência de novidade, falsa alegação de autoria ou quaisquer outros motivos. A principal reclamação era de que a legislação não conferia ao governo mecanismos ágeis e eficientes que permitissem a pronta anulação de privilégios concedidos irregularmente. O resultado era a imposição de constrangimentos à autoridade concessora e de uma sobrecarga aos tribunais, uma vez que o único meio de que eventuais prejudicados dispunham para defender seus legítimos interesses eram as ações judiciais. Constatamos que entre 1895 e 1910 praticamente todos os relatórios ministeriais apontaram a necessidade de se alterar a legislação de forma a se criar algum instrumento que permitisse à própria administração - no caso, a repartição ministerial responsável pelos serviços patentários - intervir diretamente no processo e efetuar a anulação dessas patentes indevidas. Não se tratava exatamente de críticas ao modelo de livre concessão

${ }_{18}$ Um exemplo interessante desse tipo de crítica é encontrado no relatório encaminhado ao Presidente da República pelo então Ministro da Indústria, Viação e Obras Públicas, Antônio Olyntho dos Santos Pires, informando sobre os atos de sua pasta no ano de 1895. (RELATÓRIO, 1896). 
tampouco de um discurso de defesa do exame prévio - ao contrário, este último, aplicado somente a algumas áreas, permaneceu como alvo de condenações dos mais obstinados liberais. As exortações se limitavam a apontar a necessidade de aprimoramento dos ditames legais. A despeito dos alertas, não foi apresentada nenhuma solução para esse problema no curto prazo.

Uma questão de natureza institucional mostrou-se igualmente longeva. $\mathrm{O}$ artigo 12 da CUP estabelecia que todos os países signatários deveriam manter uma repartição oficial especializada para a prestação dos serviços relacionados à propriedade industrial, o que no caso do Brasil englobava as patentes e marcas, únicos objetos até então internamente protegidos e regulamentados. Entretanto, a legislação nacional era silente quanto ao assunto e o governo nenhuma providência tomou para enfrentar essa questão. De fato, esta não constituía uma matéria nova, sendo alvo de discussões desde o Império, especialmente a partir do momento que o sistema de patentes passou a ser mais utilizado pelos produtores nacionais. Um exemplo mais evidente ocorreu em 1874, quando a SAIN encaminhou ao Ministério da Agricultura, Comércio e Obras Públicas uma proposta de reforma da Lei de 1830, consubstanciada em uma minuta de lei. Tomando como referência a legislação norte-americana, o texto previa, entre os mais diversos assuntos, a criação de uma repartição chamada Diretoria Geral das Patentes de Invenção do Império do Brasil, subordinada ao referido ministério, que ficaria responsável por todos os serviços e procedimentos relativos aos privilégios (exame, concessões, anulações, prorrogações, resolução de litígios etc.). Seu quadro técnico seria composto pelos membros das seções especializadas da SAIN, em cujos âmbitos era até então produzido o grosso dos pareceres externos requeridos pelo governo para a concessão patentes. Conforme a proposta, as decisões do órgão especializado só poderiam ser revistas pelo Conselho Administrativo da própria SAIN, em recurso de primeira instância, ou pelo Supremo Tribunal de Justiça, em última instância (PROJETO, 1874). Outra determinação importante era a transformação da revista O Auxiliador da Indústria Nacional, veículo de divulgação das atividades da entidade, em gazeta oficial da nova repartição pública, reunindo todas as informações administrativas e técnicas acerca dos pedidos e das patentes concedidas. A iniciativa evidenciava uma clara intenção da SAIN de ampliar sua autoridade no campo patentário, extrapolando-se a dimensão consultiva e conferindo à instituição poder decisório (MALAVOTA, 2020). Não encontramos registros que nos permitam aferir se o ministério acolheu a proposta e a encaminhou à Assembleia Geral Legislativa. O que sabemos, contudo, é que um projeto de lei sobre a matéria só seria discutido na Câmara dos Deputados em 1880, em moldes muito distintos da proposta formulada pela SAIN.

O debate sobre a criação de um serviço especializado no campo das patentes não se encerrou após o malogro da proposta de reforma dos anos 1870. A ideia permaneceu em discussão, conforme atestam os relatórios ministeriais produzidos na década seguinte, especialmente depois que o país ratificou a CUP. Que a criação 
de uma repartição exclusiva se mostrava útil e necessária em um contexto no qual a demanda por patentes se elevava, não havia dúvidas. Que o Brasil se via na obrigação de tomar tal providência, considerando os compromissos internacionais assumidos, igualmente. Mas o principal fator a obstar a medida parecia ser as restrições orçamentárias. Ainda nos anos 1880, Antônio Carneiro da Rocha e João Ferreira de Moura, ministros da agricultura respectivamente durante os gabinetes liberais de Sousa da Dantas e José Antônio Saraiva, admitiam a necessidade da nova repartição, porém apontavam o momento inadequado para que o governo assumisse despesas extras (RELATÓRIO, 1885). Nas duas décadas seguintes as considerações dos ministros não se modificariam. Considerando-se especialmente as políticas restritivas adotadas a partir do Governo Prudente de Morais (18941898), os discursos dos sucessivos titulares da pasta da agricultura iam ao encontro de uma diretriz mais ampla de contenção dos gastos governamentais, fator fundamental para o alcance do equilíbrio fiscal exigido pelos credores internacionais para a negociação e rolagem da dívida externa, bem como para a manutenção de canais para a tomada de novos empréstimos em moeda estrangeira.

Temos, portanto, dois fatores importantes a considerar sobre a propriedade industrial no período 1890-1910. De um lado, o crescimento da demanda por serviços de patentes e marcas; por outro os efeitos de tal tendência sobre a estrutura institucional, ou em outras palavras, sobre a capacidade desta última cumprir as suas funções.

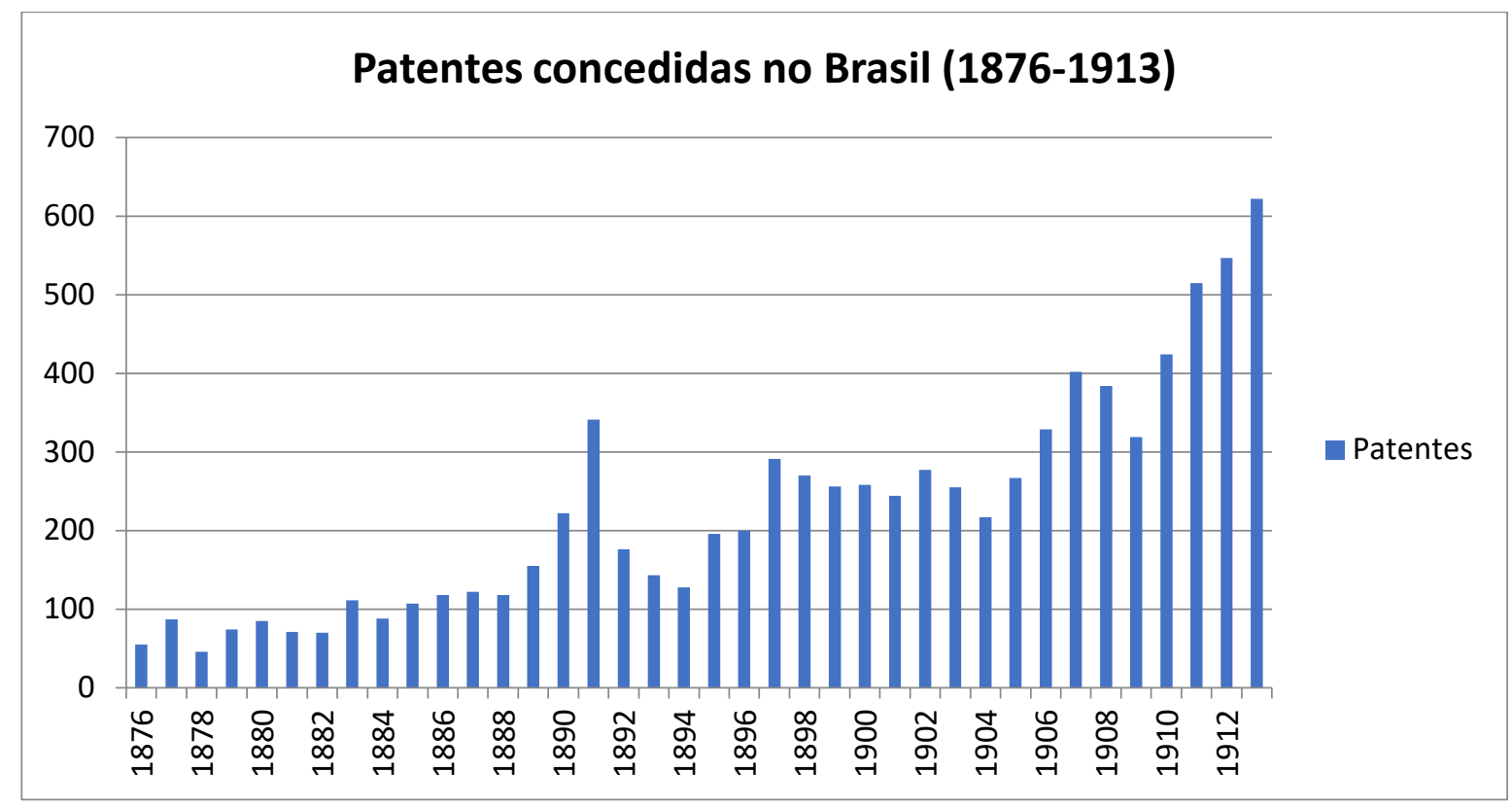

Fonte: Relatórios do Ministério da Agricultura

Em relação ao volume de depósitos, conforme já comentado, os anos 1870 apresentaram índices de patenteamento superiores aos das décadas anteriores. Embora a promulgação de uma nova legislação em 1882 tivesse entre seus objetivos 
estimular a elevação desses números - por meio do regime de livre concessão e da facilitação dos depósitos feitos por estrangeiros -, não notamos na maior parte da década de 1880 alterações significativas, mantendo-se o número de patentes anualmente concedidas relativamente estável. A tendência começa a mudar em 1889 e uma inflexão mais aguda pode ser notada no biênio 1890-1891. Atribuímos o fato ao aumento dos pedidos de patentes de bens relacionados à indústria de transformação, transportes e energia. Lembremos que a gestão de Rui Barbosa no Ministério da Fazenda (1889-1891) promoveu significativas intervenções no domínio econômico, entre elas uma reforma do sistema bancário, a promoção de uma política de emissões, expansão creditícia, desvalorização cambial, flexibilização das regras para a formação de sociedades anônimas etc. (FRANCO, 1989). As medidas expansionistas objetivavam criar bases para a elevação dos investimentos privados e a consequente aceleração do crescimento econômico. Contando com câmbio e tarifas favoráveis, crédito abundante, o aumento da liquidez no mercado e o crescimento do consumo, o setor industrial encontrou condições para sua expansão, apoiado também no ótimo momento por que passava a cafeicultura, cujos excedentes proporcionavam novas inversões em ativos alternativos. $\mathrm{O}$ surto industrial do período provocou a elevação das importações de bens de capital e a diversificação da produção, tendência que se refletiu no sistema de patentes. Se em 1880 perto de $35 \%$ das patentes concedidas estavam relacionadas a bens ou processos aplicados diretamente ao plantio, colheita ou tratamento de gêneros primários de exportação (RELATÓRIO, 1882), ${ }^{19} \mathrm{em} 1890$ esse volume é reduzido para cerca de $10 \%$. Dos 222 privilégios concedidos naquele ano, entre invenções e melhoramentos, 111 tinham como objetos bens de consumo ou de capital ligados à indústria de transformação ( $50 \%$ do total), 29 se relacionavam à agricultura ou à atividade extrativa e 27 ao setor de transportes. Os demais se distribuíam em segmentos diversos, com destaque para os de construção e energia (RELATÓRIO, 1891). No ano seguinte o número de concessões alcançou seu maior nível até então, totalizando 341, mais uma vez puxado pelo aquecimento do setor industrial. Não à toa, a tendência observada no triênio que se segue é de queda, retratando os efeitos que a chamada crise do encilhamento provocou na economia como um todo, incluindo o setor industrial..$^{20}$ Novo crescimento pode ser observado a partir de 1895, porém menos intenso, o que pode ser compreendido por um crescimento industrial mais modesto em conjuntura marcada por políticas contracionistas, estas diretamente relacionadas aos esforços governamentais em

${ }_{19}$ Póvoa e Cabello (2016) apontam que ao longo dos 52 anos de vigência da Lei de 1830 as patentes relacionadas a bens e processos aplicados à lavoura (plantio, colheita e pós-colheita) compuseram cerca de $30 \%$ do total de concessões.

${ }^{20}$ Referimo-nos à crise bancária e financeira que se seguiu à política expansionista de Rui Barbosa, caracterizada pelo estouro de uma bolha especulativa no mercado de capitais, falência ou insolvência de diversos bancos e empresas, inflação monetária e elevação generalizada dos preços (FRANCO, LAGO, 2010). 
prol do equilíbrio das contas públicas (ARIAS NETO, 2008). Somente no período 1906-1913, outro interstício marcado por um crescimento mais pujante do produto industrial, configura-se uma nova aceleração da demanda por patentes de invenção, alcançando um pico inédito ao fim desse ciclo.

Faz-se necessário ainda considerar o papel assumido pelos investimentos estrangeiros na elevação do número de patentes concedidas nas duas primeiras décadas republicanas. Analisando o período 1882-1910, Marinho (2017) identificou um total de 5.489 privilégios cujos registros permitem a determinação do país de origem do titular, classificando $48 \%$ desse conjunto como patentes estrangeiras. Norte-americanos, britânicos e franceses, respectivamente, eram os maiores depositantes. Decerto, considerando-se que a legislação brasileira não exigia a exploração local como prova do uso efetivo da invenção, boa parte desses bens patenteados era introduzida no mercado nacional via importação. Todavia, conforme alertam Suzigan e Szmrecsányi (2002), não foram poucos os exemplos de participação direta do capital estrangeiro na indústria durante a Primeira República, como parte do processo de internacionalização de grandes complexos empresariais no contexto da Segunda Revolução Industrial. A proximidade de centros produtores de insumos (como a borracha e a carne bovina, por exemplo) e a exploração do potencial de um mercado consumidor em expansão constituíram fatores de atração de capitais estrangeiros para o Brasil, alterando o padrão das inversões que vinham sendo feitos desde a década de 1870, até então concentradas no comércio de importação e exportação, nos setores de transportes e energia, bem como no complexo açucareiro. A partir dos anos 1890 os investimentos externos se diversificam, intensificando-se em segmentos industriais como o alimentício, farmoquímico, de calçados, pneus, fósforos, máquinas, veículos automotores, cimento, entre outros (SUZIGAN, SZMRECSÁNYI, 2002, p. 263-81). O crescimento observado nos níveis de patenteamento também reflete esta realidade, uma vez que as empresas que montavam unidades produtivas no país não deixavam de recorrer ao sistema de patentes como forma de proteger os novos bens tecnológicos aqui introduzidos.

No que concerne aos serviços de marcas, os registros administrativos mostramse menos consistentes e regulares, muito em razão da descentralização dos serviços. Para o interstício 1891-1899 os relatórios ministeriais em geral só apresentam informações sobre o expediente da Junta Comercial do Distrito Federal, com exceção do ano de 1893, em que se apontou a concessão de 203 marcas nos estados. Já entre 1900 e 1913, o número de registros nos estados é anualmente apresentado, ora de forma agregada ora com discriminação de registros por estado. 


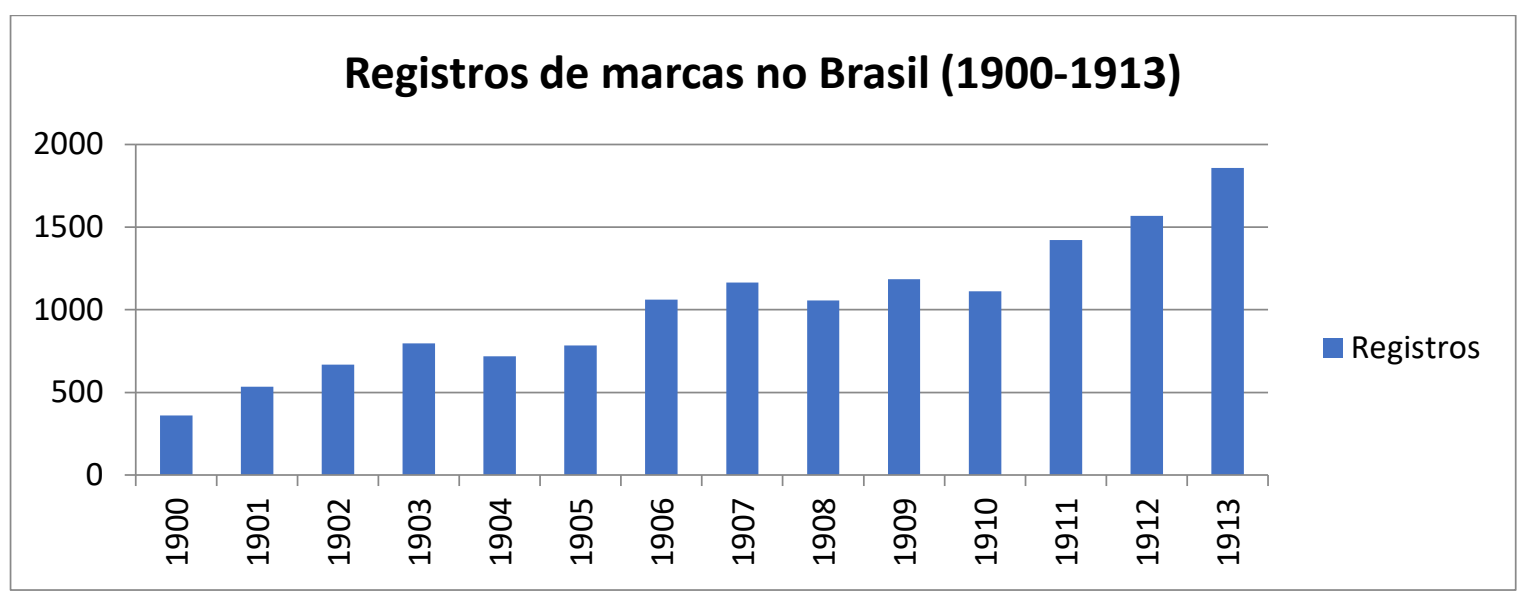

Fontes: Relatórios ministeriais.

Tanto os dados nacionais quanto os da capital nos permitem notar uma tendência de crescimento nos registros de marcas, particularmente no período 1906-1913. Assim como no caso das patentes, o ápice da série é alcançado em 1913. Notamos ainda que a elevação dos registros também passa pela influência do aumento da participação dos titulares estrangeiros, embora os pedidos feitos por nacionais tenham prevalecido durante todo o período. Cabe ressaltar que a partir de 1897 marcas estrangeiras puderam ser depositadas no Brasil por meio de pedido formulado através do bureau internacional de Berna, compondo um conjunto de registros contabilizados à parte. Os registros internacionais, entretanto, eram restritos aos titulares residentes em países signatários do Acordo de Madri.

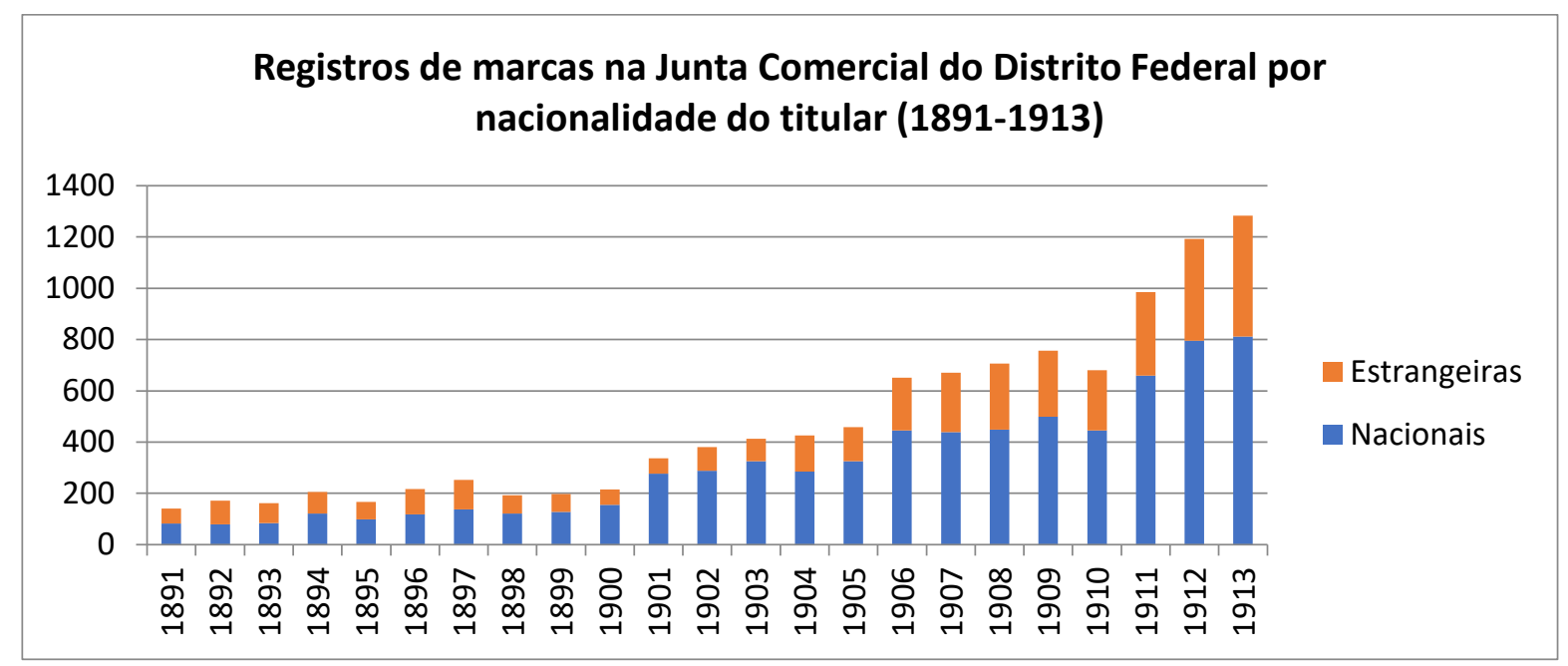

Fontes: Relatórios ministeriais.

À medida que a demanda por patentes e marcas aumentava, as inconsistências da legislação e as limitações da estrutura institucional tornavam-se mais evidentes. 
No caso das patentes, a sobrecarga imposta ao judiciário e à $1^{\underline{a}}$ Seção da Diretoria Geral da Indústria e Comércio constituía motivo de preocupação ao governo, impelindo o Ministério da Agricultura a avançar na busca por soluções. Em 1910, o ministro Rodolpho Miranda encomendou à Diretoria Geral da Indústria e Comércio um minucioso estudo acerca dos serviços patentários no Brasil, tendo em vista uma futura reforma (RELATÓRIO, 1911). Tomando-se como base as experiências de outros países, pretendia-se propor algumas medidas emergenciais no curto prazo e a construção de uma base para a discussão sobre um novo marco regulatório em tempo mais largo. $\mathrm{O}$ trabalho partia de alguns pressupostos, como a necessidade de flexibilização do requisito da novidade e da redução das exigências que envolviam o exame prévio. $\mathrm{O}$ relatório elaborado pelo ministro Pedro de Toledo, relativo aos exercícios de 1910 e 1911, acrescentou a sugestão de efetiva unificação dos serviços de patentes e marcas em uma só repartição oficial, exclusiva para este fim. O mesmo assunto também foi tratado nas mensagens anuais enviadas pelo Presidente Hermes da Fonseca ao Congresso Nacional, ratificando a intenção do governo de remodelar o arcabouço jurídico institucional de propriedade industrial (BRASIL, 1911, 1912, 1913).

O estudo desenvolvido pela Diretoria Geral da Indústria e Comércio levou cerca de dois anos para ser concluído. O próprio Diretor-Geral, José Francisco Soares Filho, subscreveu o documento, que além de contemplar diagnósticos e propostas também incorporava uma minuta de lei para ser encaminhada ao Congresso. $\mathrm{O}$ trabalho salientava a urgência da unificação dos serviços de marcas e patentes em uma única e nova repartição, tanto em razão da precariedade da estrutura então existente quanto da necessidade de centralizar a sua administração no âmbito do governo federal. Também era relembrado que a iniciativa permitiria ao país finalmente atender ao compromisso assumido com as demais nações signatárias da CUP, porém não cumprido em três décadas. Finalmente, quanto aos impactos que a nova repartição provocaria sobre o Tesouro, argumentava-se que a própria renda auferida com os serviços seria capaz de financiar os custos com pessoal e recursos materiais.

O trabalho foi encaminhado pelo ministério ao Congresso em dezembro de 1915. A conjuntura, porém, era bem distinta daquela em que fora produzido. A começar, a eclosão da Grande Guerra provocou forte impacto sobre o comércio internacional e a economia brasileira não ficou imune aos desdobramentos do conflito europeu. A retração do fluxo internacional de bens e capitais afetou primeiramente a agroexportação, em face da redução da demanda. A indústria, ainda que inicialmente estimulada pelo estrangulamento das importações, encontrou na capacidade ociosa o seu limite de expansão, já que a guerra também reduzira drasticamente a oferta de bens de capital no mercado internacional. Decerto esse gargalo provocou o incremento da produção da indústria pesada nacional, mas não a ponto de atender os níveis de demanda. Somando-se a isso a redução dos excedentes da agricultura, o que reduzia as margens para 
investimento em outras atividades, a aceleração industrial do período pré-guerra perdeu um pouco do seu vigor. Compunham ainda o quadro novas medidas de contenção dos gastos públicos, consequências de mais um processo de reestruturação da dívida externa promovido ao fim do governo de Hermes da Fonseca.

Mais uma vez a tendência se reflete no número de patentes concedidas. Entre 1914 e 1918 assistimos a uma redução do número de privilégios, acompanhando o desaquecimento da atividade industrial e o declive da curva de investimentos estrangeiros. Somente em 1920 são retomados e superados os patamares do período pré-guerra, já em um contexto econômico mais favorável, marcado pela elevação dos preços das commodities primárias no mercado internacional e pela intensificação dos fluxos internacionais de bens e capitais.

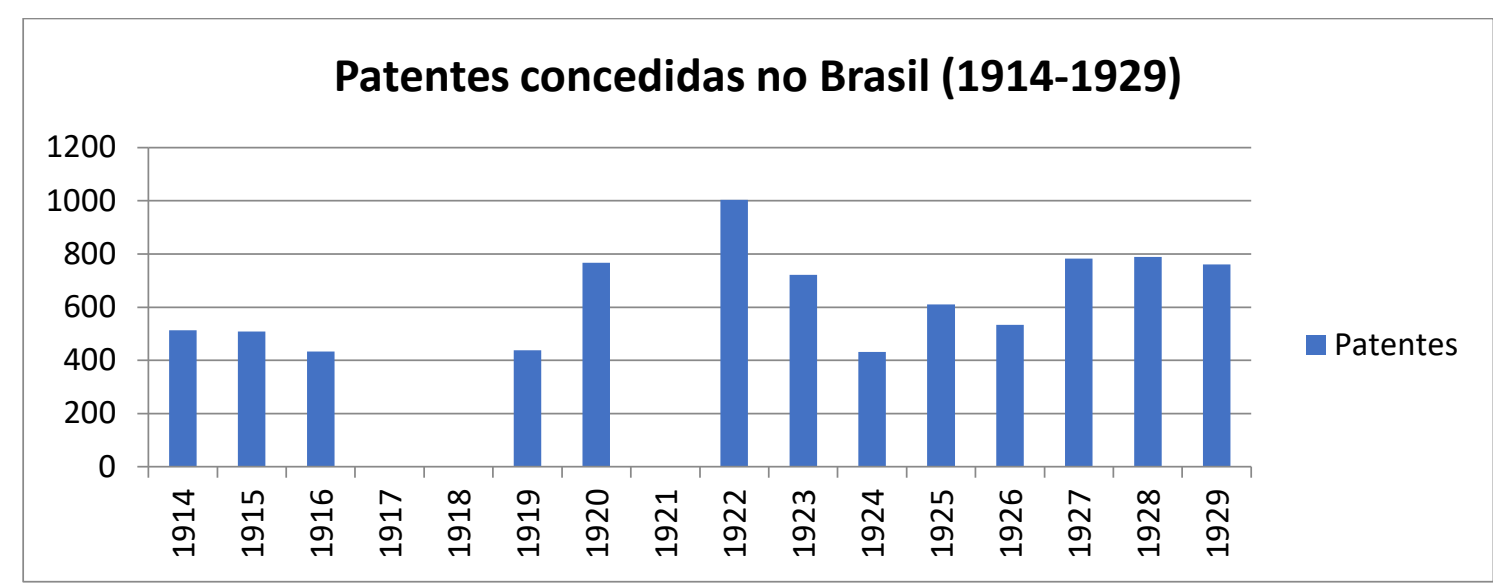

A documentação não apresenta informações sobre os anos de 1917, 1918 e 1921

Percebemos, pois, que a proposta de reforma dos sistemas de patentes e marcas chegou ao Congresso Nacional em uma conjuntura complicada. No plano econômico, as dificuldades provocadas pela Grande Guerra, a estagnação interna e o aperto da liquidez pressionavam o governo a redobrar esforços em prol do equilíbrio fiscal, o que significava contenção de gastos do setor público (FRITSCH, 1989). Em outro front, a elevação do custo de vida, a pressão sobre os salários e as precárias condições de trabalho na indústria estimularam o descontentamento e a mobilização da classe trabalhadora, culminando com a eclosão de uma série de greves em 1917 (LOPREATO, 2000). Nesse cenário de instabilidade, a propriedade industrial não parecia ser um tema prioritário. Além disso, a momentânea retração da demanda pelos serviços, conforme pudemos observar, contribuía para o alívio das pressões por intervenções imediatas. Notamos, com isso, que durante o Governo de Venceslau Brás (1914-1918) o debate sobre a reforma pouco avançou no Executivo e no Legislativo. Diferentemente do quadriênio anterior, tanto os relatórios ministeriais quanto as mensagens presidenciais simplesmente não trataram do assunto. A questão parece ter sido excluída da agenda governamental ou, ao menos, relegada a segundo plano. 


\section{TEMPOS DE REFORMA: A NOVA LEGISLAÇÃO DE PROPRIEDADE INDUSTRIAL E A CRIAÇÃO DA DIRETORIA GERAL DA PROPRIEDADE INDUSTRIAL}

Somente em 1920, talvez estimulada pelo otimismo da recuperação econômica do imediato pós-guerra, a reforma da propriedade industrial voltou a ser matéria de debate. A iniciativa partiu do Ministério da Agricultura, que encaminhou ao Congresso uma minuta de lei formulada pelo então Diretor Geral da Indústria e Comércio, Raimundo de Araújo Castro. As motivações não eram muito distintas das que vinham sendo alegadas havia cerca de uma década, conforme atesta depoimento prestado pelo próprio Diretor Geral ao jornal A Noite, publicado na edição de 24 de julho (A CREAÇÃO, 1924). No que concerne às patentes, os problemas causados pela concessão de privilégios irregulares (especialmente a objetos sem novidade), a precariedade da estrutura burocrática vigente e a necessidade de se atender às exigências impostas por acordos internacionais. Quanto às marcas, a inadequação de um sistema descentralizado, a precariedade dos registros administrativos das Juntas Comerciais e a conveniência da federalização dos serviços. Contudo, a referida minuta, posteriormente formalizada como um projeto de lei, apresentava novidades em relação à proposta de 1915. A mais importante era a abolição do sistema de livre concessão, retomando-se a aplicação do exame prévio a todos pedidos, como forma de aferição de sua adequação aos ditames legais. Não apenas os formais, como até então era feito, mas também os substantivos, como o atendimento dos requisitos de patenteabilidade. Araújo Castro classificava a medida como a melhor forma de defender os interesses do inventor. Para ele, era injusto obrigar a um indivíduo lesado em seus direitos a ter que arcar com os custos e os inconvenientes de uma ação judicial para defender os seus interesses. Além disso, apontava que países como os Estados Unidos e a Argentina adotavam com sucesso o sistema de exame, constituindo exemplos a serem seguidos.

A discussão do projeto de lei provocou a reação de segmentos da sociedade civil diretamente interessados na matéria. Em um artigo originalmente publicado na edição de maio de 1921 na Revista Comercial do Brasil, posteriormente reproduzido no Jornal do Commercio do Rio de Janeiro, Isidoro Campos, Diretor da Secretaria da Junta Comercial do Distrito Federal, efetuou severas críticas à reforma proposta pelo governo (CAMPOS, 1921). Na opinião do articulista, era inegável que a legislação de patentes precisava ser alterada em alguns pontos, mas os ajustes necessários seriam de pequena monta, não exigindo medidas de grande impacto. Em sua opinião, a criação de uma nova repartição pública especializada, conforme queria o governo, constituiria ação de pouca utilidade e traria um peso desnecessário ao Tesouro - e consequentemente aos bolsos dos contribuintes. Nem mesmo o atendimento a compromissos internacionais eram tomados pelo autor como justificativa plausível, uma vez que considerava a adesão do Brasil à CUP uma medida deletéria ao país, dadas as reduzidas vantagens proporcionadas 
aos produtores nacionais vis-à-vis os concorrentes estrangeiros. Campos argumentava ainda que sua posição era corroborada por boa parte do setor produtivo, conforme evidenciado nos debates ocorridos durante o II Congresso de Expansão Econômica, promovido na capital federal naquele mesmo ano. $\mathrm{Na}$ ocasião, uma das resoluções do Congresso recomendou cautela ao governo em relação à reforma jurídico-institucional, entendendo-se que mais útil do que a centralização dos serviços em uma única repartição federal seria direcionar esforços e recursos para a criação e aparelhamento de tribunais especializados, estes voltados ao julgamento de litígios e infrações aos direitos de propriedade industrial. Para os participantes do evento, este era o problema mais grave a ser enfrentado pelo poder público. A crítica presente no artigo de Isidoro Campos, portanto, voltava-se à debilidade dos instrumentos de repressão e controle sobre a infração aos direitos dos titulares de patentes e marcas, não às questões administrativas que envolviam a propriedade Industrial. Além disso, duvidava-se que os custos de uma estrutura burocrática complexa pudessem ser facilmente assumidos pelo governo - pelo menos não sem a criação de fontes adicionais de recursos. Uma reforma institucional bem executada exigiria a formação de um quadro numeroso de funcionários, devidamente treinado e equipado para o cumprimento de suas tarefas. Argumentava que sendo inviável uma repartição oficial aos moldes do escritório norte-americano, por exemplo, qualquer outro arranjo seria dispendioso e ineficaz. Mais interessante seria apostar no modelo vigente havia quase quatro décadas, porém fazendo-se os ajustes pontuais necessários e capacitando-se o judiciário para o cumprimento das atribuições previstas em lei.

A despeito das críticas, o projeto seguiu seu curso no Congresso. Lentamente, diga-se de passagem. Foi preciso o aumento das pressões externas para que o mesmo finalmente fosse aprovado. Um acontecimento importante para o desfecho desse processo ocorreu em outubro de 1922. Como era praxe nas Grandes Feiras Universais, durante os trabalhos da Exposição do Centenário da Independência foram realizados diversos congressos, seminários e outras reuniões técnicas, profissionais e científicas, aproveitando-se a visibilidade oferecida por um evento de grandes dimensões. Dentre os diversos foros que ali tiveram lugar, destacamos o Congresso Jurídico Comemorativo da Independência do Brasil. Organizado pelo Instituto da Ordem dos Advogados Brasileiros, o evento constituía uma iniciativa em favor da organização do campo jurídico no Brasil, concorrendo para a reunião de grandes especialistas e a discussão de temas relevantes dentro da área do direito. Seus trabalhos foram divididos em nove seções temáticas, cada uma presidida por um jurista, responsável pela escolha dos membros das mesas e dos pareceristas, bem como da formulação de questionários e teses preliminares que pautavam as discussões e deliberações (GALVÃO, 2017). Uma delas foi a seção de Direito Industrial, presidida por Augusto Olímpio Viveiros de Castro, ministro do Supremo Tribunal Federal. Dentre os diversos temas discutidos em seu âmbito, 
ganhou destaque o da propriedade industrial, o que obviamente passou pelo debate sobre a reforma pretendida pelo governo. Uma das deliberações da seção prestou apoio à proposta que vinha sendo negociada no Congresso e apresentou justificativas. A unificação dos registros de marcas em um só órgão foi um dos pontos mais defendidos, apontando-se não apenas a natureza federal desse tipo de serviço, mas também a necessidade de se combater a ação de fraudadores e exploradores do trabalho alheio, facilitada pela dispersão administrativa. Além disso, alertou-se para as constantes irregularidades observadas em patentes em vigor, consequências do regime de livre concessão. Ao fim, recomendou-se ao governo dar prosseguimento aos esforços visando à unificação dos serviços de patentes e marca, colocando-os sob a responsabilidade de uma única repartição federal (ABAPI, 1998).

No orçamento da União para o exercício de 1923, aprovado pelo legislativo em janeiro daquele ano, as despesas relativas à nova repartição já foram devidamente lançadas (BRASIL, 1924b). Matéria publicada no Jornal do Commercio, em 4 de maio, destacou a iminente criação do novo órgão e mais uma vez apresentou as justificativas do governo para a medida. Além dos diversos argumentos anteriormente elencados, acrescentava-se a informação de que os quadros da nova instituição seriam compostos por pessoal deslocado de outros órgãos governamentais, dispensando a abertura de novas vagas no serviço público (PROPRIEDADE, 1923). Fato importante também ocorrido naquele ano foi a criação do Conselho Superior do Comércio e Indústria, órgão colegiado de assessoria à Presidência da República (BRASIL, 1923). Entre os distintos temas sobre os quais a instância deveria opinar incluía-se a propriedade industrial. ${ }^{21}$ Pavimentava-se o caminho para que assim que o projeto de lei fosse aprovado uma nova estrutura jurídico-institucional fosse erigida. Finalmente, em 19 de dezembro de 1923, foi promulgado o Decreto n.o 16.264, criando a Diretoria Geral da Propriedade Industrial e estabelecendo uma nova legislação sobre patentes e marcas (BRASIL, 1924a).

No que concerne aos aspectos legais, conforme já esperado, mudanças significativas foram implementadas. Talvez a mais evidente tenha sido a extensão do exame prévio a todos os pedidos de patentes. Embora a prática não fosse exatamente uma novidade no Brasil, no novo regime ela se mostrou inovadora, uma vez que agora a responsabilidade técnica do exame prévio era atribuída à própria repartição oficial de propriedade industrial, não mais a consultores

${ }^{21}$ Presidido pelo Ministro da Agricultura, Indústria e Comércio, o Conselho Superior do Comércio e Indústria era composto por 40 membros, entre representantes de diversos órgãos do governo, de entidades empresariais e especialistas escolhidos pelo ministério. Como seu próprio nome indica, sua jurisdição se estendia a todos os assuntos relacionados à indústria e ao comercio, atuando sempre que provocada por consultas governamentais ou por iniciativa própria, nas ocasiões que considerasse conveniente prestar auxílio ou esclarecimento aos poderes públicos. A comissão não era remunerada, exceto o cargo de Secretário-Geral. 
externos. Facultava-se ao novo órgão recorrer a consultores ad hoc recrutados dentro do próprio serviço público federal, mas como recurso de suporte em caso de necessidade, não como regra. A legislação também introduzia a publicação prévia do relatório descritivo dos pedidos de patente e criava uma nova modalidade de privilégio, o modelo de utilidade, aplicável a aperfeiçoamentos introduzidos na disposição ou na forma de objetos já conhecidos, desde que com efeitos técnicos sobre os mesmos (ABRANTES, 2014). O prazo de vigência das patentes de invenção era de 15 anos, cinco a mais do que o dos modelos de utilidade. Uma vez cumpridas as exigências formais dos depósitos, o órgão oficial tinha até 30 dias para efetuar os exames prévios, nos quais seriam aferidos os requisitos de patenteabilidade (novidade e aplicabilidade industrial), bem como a suficiência das informações prestadas pelo inventor sobre as invenções. Previa-se ainda a possibilidade de desapropriação de patentes em caso de interesse público, mediante as formalidades legais. Já quanto às principais permanências em relação à legislação patentária anterior destacamos os certificados de melhoramento, os títulos de garantia provisória, a previsão de mecanismos para cessão e transferência de direitos, bem como a previsão de penas a infrações dos direitos dos titulares. Cabe por último ressaltar que a legislação de 1923 estabelecia a caducidade em casos de ausência de uso efetivo da invenção, porém era silente quanto ao que determinava esse uso efetivo. De tal modo, depreendemos que não havia, pelo menos na letra da lei, qualquer restrição à importação como forma de uso da invenção, o que desobrigava a exploração local.

No que diz respeito às marcas, a grande mudança foi a unificação dos serviços na Diretoria Geral da Propriedade Industrial, embora os interessados pudessem, para fins de garantia de prioridade, dar entrada nos pedidos nas Juntas Comerciais dos estados em que possuíam domicílio (o mesmo se aplicava aos pedidos de patentes). Tratava-se, portanto, de uma possibilidade facultada aos interessados residentes fora da capital federal, tendo em vista facilitar a protocolação dos processos. Toda a tramitação administrativa, entretanto, era de responsabilidade do órgão oficial. O novo marco legal também abria possibilidade para recursos na esfera administrativa em caso de denegação de pedidos de privilégios ou registros de marcas. Estes deveriam ser encaminhados ao Ministério da Agricultura, Indústria e Comércio em um prazo de até 60 dias a partir da publicação da decisão da Diretoria Geral da Propriedade Industrial.

Embora não muito significativa, a reforma teve em geral uma repercussão positiva junto à opinião pública. Importantes veículos de comunicação da capital, como o Jornal do Commercio e A Noite, divulgaram notas elogiando a iniciativa do governo e expondo as justificativas para as medidas (EXAME, 1923; REMODELA-SE, 1923). Também a exposição de motivos feita pelo então Ministro da Agricultura, Indústria e Comércio, Miguel Calmon Du Pin e Almeida, foi reproduzida pela imprensa (EXPOSIÇÃO, 1923). A Associação Comercial do Rio de Janeiro igualmente se pronunciou sobre o assunto, defendendo a nova legislação 
e a criação da agência oficial de propriedade industrial (ASSOCIAÇÃO, 1923). Em sessão ordinária de sua diretoria, Othon Leonardos opinava que os institutos de propriedade industrial no Brasil mostravam-se anacrônicos e que os serviços eram até então prestados de modo precário, o que por si só justificava a intervenção governamental. Defendia o exame prévio como medida saneadora e protetora dos inventores, além de aliviar a sobrecarga imposta ao judiciário. A centralização do registro de marcas, a possibilidade de recursos administrativos e as alterações nas regras para busca e apreensão também eram tomadas como medidas favoráveis aos usuários do sistema de propriedade industrial. Por fim, recomendava que a associação prestasse oficialmente um voto de louvor e agradecimento ao Presidente da República, ao ministro Miguel Calmon e ao idealizador do projeto, Raimundo de Araújo Castro.

A Diretoria Geral da Propriedade Industrial foi instalada provisoriamente em parte do pavilhão construído pela representação do México por ocasião da Exposição Universal de 1922, localizado na Avenida das Nações, região central do Rio de Janeiro. ${ }^{22}$ Seus trabalhos foram efetivamente iniciados em 5 de março de 1924 (RELATÓRIO, 1928b). Nesse mesmo ano teve início a publicação da Revista da Propriedade Industrial, novo veículo oficial de divulgação de informações pedidos, concessões e outros atos administrativos envolvendo patentes e marcas, substituindo o Boletim da Propriedade Industrial, criado em 1907. O primeiro Diretor Geral nomeado foi Manoel Cícero Peregrino da Silva, ex-diretor da Biblioteca Nacional. De acordo com o regulamento do órgão, seu quadro de servidores era bastante reduzido, contando com pouco mais de uma dezena de oficiais e alguns funcionários de apoio ao expediente - datilógrafos, porteiros, contínuos, serventes, etc. (BRASIL, 1924a). Inicialmente, apenas 3 pessoas ficariam responsáveis pelo exame prévio das patentes, sendo denominados consultores técnicos, priorizando-se profissionais das áreas de química, mecânica e engenharia civil (A CREAÇÃO, 1920). Em nota publicada na imprensa, em 13 de maio de 1924, Manoel Peregrino esclarecia que a repartição já estava em pleno funcionamento e contava com 12 servidores, divididos em quatro setores: Gabinete; Seção de Patentes; Seção de Marcas; Portaria. (O DIRETOR, 1924). A despeito do que estabelecia o seu regulamento, àquela altura o órgão contava somente com um consultor técnico, o biólogo e químico Carlos Ernesto Júlio Löhman. ${ }^{23}$ Dois anos

\footnotetext{
${ }^{22}$ A antiga Avenida das Nações, que abrigou os pavilhões nacionais que compuseram a Exposição do Centenário de 1922, estendia-se do Palácio Monroe (ao fim da atual Avenida Rio Branco) à Ponta do Calabouço (região do atual Museu Histórico Nacional).

${ }^{23}$ Carlos Ernesto Julio Lohman era natural dos Países Baixos e fora convidado a trabalhar no Brasil por Miguel Calmon Du Pin e Almeida. Também trabalhou no Museu Nacional e lecionou na Escola Politécnica (CARNEIRO, 2004). Considerando que desde o período imperial o exame prévio das patentes fora efetuado por consultores externos, que não cumpriam tal atividade de forma exclusiva, podemos inferir que Lohman foi, de fato, o primeiro examinador de patentes profissional do Brasil.
} 
depois esse número se elevaria a cinco, sendo três deles do quadro efetivo do órgão e os demais servindo em comissão (RELATÓRIO, 1928a). Finalmente, em 1928, mais dois servidores foram requisitados de outros órgãos para reforçar o corpo de consultores (RELATÓRIO, 1929).

Uma questão importante a considerar era justamente a atuação dos chamados consultores técnicos, os examinadores de patentes de então. Parece claro que o número de profissionais desde o início planejado era insuficiente para dar conta da demanda. Já desde os primeiros relatórios ministeriais produzidos após a criação da nova repartição as menções sobre a escassez de pessoal para o exame estavam presentes. As informações sobre o ano de 1926, por exemplo, dão conta que 1.209 pedidos de privilégio de invenção haviam sido depositados, sendo concedidas no mesmo ano 533 patentes (RELATÓRIO, 1928a). Não há registros sobre o número de pedidos denegados ou arquivados por questões formais, por isso não é possível aferir com precisão a diferença entre o número de depósitos e de decisões. Mas tudo indica que já desde o início dos trabalhos do novo órgão um backlog foi formado, situação inexistente no regime anterior. Outro indício da inadequação do quadro funcional era o fato da instituição recorrer frequentemente a consultores externos para a realização dos exames, ainda que a legislação classificasse esse suporte como um ato extraordinário. Citamos como exemplo, neste mesmo exercício de 1926, o relatório das atividades desempenhadas pela Estação Experimental de Combustíveis e Minérios, órgão do Ministério da Agricultura, que informava ter emitido naquele ano 85 pareceres sobre patentes por solicitação da Diretoria Geral da Propriedade Industrial (RELATÓRIO, 1928a). Outros órgãos usualmente chamados a apoiar o expediente da repartição eram a Diretoria Geral de Saúde Pública, o Instituto de Química, a Diretoria de Material Bélico, o Serviço de Inspeção e Fomento Agrícolas, o Instituto Biológico, a Engenharia Naval, o Museu Nacional e a Assistência Hospitalar do Brasil (RELATÓRIO, 1929).

Conforme já comentado, a nova legislação abria aos usuários a possibilidade de recursos na esfera administrativa, que deveriam ser encaminhados ao Ministério da Agricultura. Coube ao Conselho Superior do Comércio e Indústria assessorar o ministro nessa tarefa. Todos os assuntos tratados pelo órgão colegiado eram discutidos no âmbito de suas comissões permanentes, cada uma delas formada por três membros. Duas dessas comissões dedicavam-se exclusivamente ao tema da propriedade industrial, uma para patentes e outra para marcas. Cabia a seus membros a apreciação dos recursos, elaborando um parecer para discussão no plenário do Conselho, que tomava as decisões por delegação de competência do Ministro da Agricultura. Assim como a repartição oficial, também essa instância se mostrou de pronto sobrecarregada, apresentando anualmente um total de despachos inferior ao número de recursos protocolados. Eram justamente as duas comissões dedicadas à propriedade industrial (a oitava e a nona, respectivamente incumbidas dos assuntos de patentes e marcas) que tinham o maior volume de processos. Para que se tenha uma ideia, em 1929 foram apreciados pelo plenário do 
Conselho 300 processos, sendo 167 oriundos da comissão de patentes, 131 da comissão de marcas e apenas 2 de todas as demais reunidas (RELATÓRIO, 1930). Além do excesso de carga de trabalho eram comuns as reclamações dos membros das comissões em relação aos prazos exíguos impostos para apreciação dos recursos - 30 dias, prorrogáveis por igual período.

Em 1929 a Diretoria Geral da Propriedade Industrial foi transferida para as dependências do Ministério da Agricultura, ocupando o 5o andar do Palácio da Agricultura, edifício localizado na Praça Marechal Âncora, Centro do Rio de Janeiro (RELATÓRIO, 1930). À época, o então Ministro da Agricultura, Geminiano Lyra, alertava mais uma vez o governo sobre a necessidade de expandir o corpo funcional da instituição, solicitando a abertura de mais vagas para examinadores de patentes, com prioridade para especialistas na área de química industrial. Àquela altura o principal esforço da administração era o combate ao backlog, tanto em patentes quanto em marcas. Também havia atrasos nas análises dos depósitos via Acordo de Madri, o que exigiu naquele ano uma força-tarefa para reduzir o passivo. $\mathrm{O}$ número de depósitos assumia tendência ascendente enquanto o número anual de decisões era relativamente estável. A participação dos estrangeiros contribuiu bastante para o aumento da demanda pelos serviços, de tal modo que entre $1924 \mathrm{e}$ 1930 os depósitos feitos por não residentes corresponderam a 72,5\% do total (O MINISTÉRIO, 1936). Ao fim da Primeira República, os gargalos da nova estrutura institucional se mostravam cada vez mais evidentes.

\section{CONSIDERAÇÕES FINAIS}

Ao longo desta reflexão pudemos notar como foram construídos na Primeira República distintos modelos jurídicos para a regulação dos direitos de propriedade industrial. No que concerne às patentes, um primeiro ciclo, estabelecido no interstício 1890-1923, foi caracterizado por um regime de livre concessão - exceto para fármacos, produtos químicos e alimentos - , a inexistência de uma repartição oficial exclusiva e especializada para o tratamento das questões relacionadas aos privilégios e a utilização de consultores externos para a execução dos exames técnicos nos casos das exceções previstas por lei. Observamos também que a demanda por serviços esteve particularmente atrelada às tendências da atividade industrial, acompanhando suas expansões e retrações. Também notamos uma participação crescente dos não residentes nos pedidos e concessões efetuados no Brasil. Já no que tange às marcas, o referido ciclo foi caracterizado pela descentralização administrativa e pela predominância dos depósitos nacionais, porém acompanhada por uma tendência ascendente de depósitos estrangeiros via Acordo de Madri. Também percebemos uma discrepância bastante acentuada entre o número de pedidos estrangeiros encaminhados pelo BIRPI ao Brasil (ou mais exatamente, à Junta Comercial do Distrito federal, responsável pela administração desses processos) e os pedidos encaminhados pelo Brasil ao escritório de Berna. 
Essa questão mostrar-se-ia relevante no contexto da Era Vargas, contribuindo para a saída do Brasil do Sistema de Madri.

Nossa periodização aponta a formação de um novo ciclo no interstício 19241933, embora, para efeitos do nosso trabalho, consideraremos somente seus sete primeiros anos. O interstício é caracterizado principalmente pela unificação dos serviços de patentes e marcas, a criação da primeira instituição oficial de propriedade industrial do país e a adoção do regime de exame prévio. Em um momento em que a demanda pelos serviços ascendia ano a ano, a nova estrutura administrativa, que também passava a incorporar uma instância recursal, mostrouse insuficiente para o desempenho das funções de que tinha sido legalmente incumbida. Ao fim da década de 1920, as expectativas iniciais em relação ao novo modelo já se mostravam frustradas. Se muitos dos problemas evidenciados no ciclo anterior haviam sido reduzidos, por outro lado problemas de novo tipo imediatamente surgiram, especialmente o backlog processual. Não chegamos a investigar os impactos provocados pelo novo modelo sobre o Judiciário.

O ano de 1930 trouxe transformações significativas à ordem política nacional. A conjunção de uma crise econômica global - com fortes efeitos sobre os preços internacionais das commodities primárias -, a ascensão de ideários antiliberais e uma reconfiguração das alianças oligárquicas criaram as condições para uma drástica ruptura institucional. Um movimento civil-militar deflagrado em outubro daquele ano depôs o presidente Washington Luís (1926-1930) e instalou um novo governo, liderado pelo político gaúcho Getúlio Vargas, candidato derrotado nas eleições presidenciais ocorridas sete meses antes. A instalação do novo regime resultou de uma ação conjunta de oligarquias dissidentes, camadas médias urbanas, militares e outros grupos sociais descontentes com o modelo político que sustentava a Primeira República, este baseado no federalismo dual e na restrição do acesso aos mecanismos de representação política. Uma nova fase da história do país tinha início a partir de então.

Em meio a rupturas e turbulências, tentava se equilibrar a Diretoria Geral da Propriedade Industrial. Nascida com um espírito modernizador, as circunstâncias pareciam atropelá-la. Desde sua fundação, seus problemas auferiam maior destaque do que as soluções por ela apresentadas. Se a repartição havia sido concebida como instrumento para a adequação do sistema de propriedade industrial às necessidades de uma economia em transformação, suas limitações não tardaram a aparecer. Os objetivos vislumbrados pela reforma não foram plenamente alcançados, dadas as condições precárias em que a instituição atuava.

É com essa situação que se depara o Governo Provisório instalado ao fim de 1930. Este de pronto efetua uma profunda reforma no primeiro escalão da administração federal, que entre outras medidas cria o Ministério do Trabalho, Indústria e Comércio. Os negócios da propriedade industrial são lançados à sua jurisdição e a Diretoria Geral fica subordinada ao novo ministério. Nova reforma seria imposta ao arcabouço jurídico-institucional que regulava a matéria, tomado 
pelo novo governo como aquém das necessidades dos setores produtivos e incapaz de responder aos desafios que os novos tempos impunham. $\mathrm{O}$ ano de 1931 marca o fim da curta existência do primeiro escritório oficial de patentes e marcas do Brasil. A Era Vargas propunha um novo modelo de administração da máquina pública e a propriedade industrial não ficaria imune a esse projeto. Mas esse é um assunto que extrapola os limites de nossa reflexão. Esperamos poder enfrentá-lo em momento oportuno.

\section{REFERÊNCIAS}

A CREAÇÃO da D.G. de Propriedade industrial. A Noite, Rio de Janeiro, ano 10, n. 3.096, p. 1, 24 jul. 1920.

ABRANTES, A.C.S. Patentes de modelos de utilidade no Brasil. Rio de Janeiro: Lumen Juris, 2014.

ANDRADE, R.G. Burocracia e economia na primeira metade do século XIX (A Junta do Comércio e as atividades artesanais e manufatureiras na cidade do Rio de Janeiro: 18081850). 1980. Dissertação (Mestrado em História) - UFF, Niterói, 1980.

ALMEIDA, P.R. Formação da diplomacia econômica no Brasil: as relações econômicas internacionais do Império. São Paulo: SENAC/FUNAG, 2001.

ARIAS NETO, J.M. Primeira República: economia cafeeira, urbanização e industrialização. In: FERREIRA, J.; DELGADO, L.A.N. O tempo do liberalismo excludente: da Proclamação da República à Revolução de 1930. 3 ed. Rio de Janeiro: Civilização Brasilira, 2008, p. 191-230 (O Brasil Republicano, v. 1).

ABAPI. Propriedade industrial no Brasil: 50 anos de história. São Paulo: Associação Brasileira dos Agentes da Propriedade industrial, 1998.

ASSOCIAÇÃO Comercial. Jornal do Commercio, Rio de Janeiro, ano 97, n. 357, p. 3 , 28 dez. 1923.

BAILLY, G.A. Protection des inventions au Brésil. Paris: M. Giard \& E. Brière, 1915.

BARBOSA. A.L.F. Propriedade e quase propriedade no comércio de tecnologia. Brasília, CNPq, 1981.

BARBOSA. D.B. Tratado da Propriedade Intelectual. Tomo I. Rio de Janeiro: Lumen Juris, 2010. 
BARBOSA, R. Obras Completas de Rui Barbosa. V.2, Tomo 1 (1872-1874) Trabalhos Jurídicos. Rio de janeiro: Fundação Casa de Rui Barbosa, 1984.

BIATO, F.A.; GUIMARÃES, E.A.: FIGUEIREDO, M.H.P. A transferência de tecnologia no Brasil. Brasília: IPEA/IPLAN, 1973.

BRASIL. Câmara dos Deputados. Anais do Parlamento Brasileiro. Câmara dos Srs. Deputados. Segundo ano da décima oitava legislatura. Sessão de 1882 (prorrogação). V. 5. Rio de Janeiro: Typographia Nacional, 1882.

BRASIL. Decreto n. ${ }^{\circ}$ 2.682, de 23 de outubro de 1875. Regula o direito que têm o fabricante e o negociante, de marcar os productos de sua manufactura e de seu commercio. Coleção de Leis do Império do Brasil de 1875. V.1, Tomo XXIV, Parte I, 1876, p. 179-182.

BRASIL. Decreto n. 2.748, de 16 de fevereiro de 1861. Organisa a Secretaria de Estado dos Negocios da Agricultura, Commercio e Obras Públicas. Coleção de Leis do Império do Brasil de 1861. Tomo XXIX, Parte II. Rio de Janeiro: Typographia Nacional, 1861, p. 129-41.

BRASIL. Decreto n. ${ }^{\circ}$ 8.820, de 30 de dezembro de 1882. Approva o Regulamento para execução da Lei n.3129 de 14 de Outubro de 1882. Coleção de Leis do Império do Brasil de 1882. V.2, Tomo XLV, Parte II. Rio de Janeiro: Typographia Nacional, 1883, p. 636-57.

BRASIL. Decreto n. 9 9.801, de 5 de fevereiro de 1887. Declara a intelligencia de algumas disposições da Lei n. 3129 de 14 de Outubro de 1882. Coleção de Leis do Império do Brasil de 1887. V.2. Rio de Janeiro: Typographia Nacional, 1888, p. 431.

BRASIL. Decreto n. ${ }^{\circ}$ 16.009, de 11 de abril de 1923. Crêa o Conselho Superior de Commercio e Indústria. Colecção das leis da República dos Estados Unidos do Brasil de 1923. V. 2. Rio de Janeiro: Imprensa Nacional, 1923, p. 210-3.

BRASIL. Decreto n. ${ }^{\circ}$ 16.264, de 19 de dezembro de 1923. Crêa a Directoria Geral da Propriedade Industrial. Colecção das leis da República dos Estados Unidos do Brasil de 1923. V. 3, Parte 1. Rio de Janeiro: Imprensa Nacional, 1924a, p. 329-53.

BRASIL Lei n. ${ }^{\circ}$ 3.129, de 14 de outubro de 1882. Regula a concessão de patentes aos autores de invenção ou descoberta industrial. Coleção de Leis do Império do Brasil de 1882. Parte I, V.I, Tomo XXIX, Parte I. Rio de Janeiro: Typographia Nacional, 1883. p. 82-8. 
BRASIL. Lei n. ${ }^{\circ}$ 4.632, de 6 de janeiro de 1923. Fixa a Despesa Geral da Republica dos Estados Unidos do Brasil para o exercício de 1923. Colecção das leis da República dos Estados Unidos do Brasil de 1923. V. 1. Rio de Janeiro: Imprensa Nacional, 1924b, p. 10-85.

BRASIL. Mensagem apresentada ao Congresso Nacional na abertura da terceira sessão da sétima legislatura pelo Presidente da República Marechal Hermes Rodrigues da Fonseca. Rio de Janeiro: Imprensa Nacional, 1911.

BRASIL. Mensagem apresentada ao Congresso Nacional na abertura da primeira sessão da oitava legislatura pelo Presidente da República Marechal Hermes Rodrigues da Fonseca. Rio de Janeiro: Imprensa Nacional, 1912.

BRASIL. Mensagem apresentada ao Congresso Nacional na abertura da segunda sessão da oitava legislatura pelo Presidente da República Marechal Hermes Rodrigues da Fonseca. Rio de Janeiro: Imprensa Nacional, 1913.

CAMPOS, I. O regime de patentes de invenção e marcas de fábrica. Jornal do Commercio, Rio de Janeiro, ano 95, n. 161, p. 8, 12 jun. 1921.

CARDOZO, A.C. The implementation of laws and regulations on transfer of technology: the experience of Brazil. [S.1.]: UNCTAD Secretariat, 1990.

CARNEIRO, P.E.B. Depoimento. In: MAIO, M.C. (org). Ciência, política e relações internacionais: ensaios sobre Paulo Carneiro. Rio de Janeiro: Editora Fiocruz;

UNESCO, 2004, p. 269-308. Disponível em:

http://books.scielo.org/id/fczgd/epub/maio-9788575415092.epub. Acesso em: 09 jul. 2020.

CARVALHO, J.M. A construção da ordem: a elite imperial. Teatro das sombras: a politica imperial. 3 ed. Rio de Janeiro: Civilização Brasileira, 2007.

CARVALHO, N.P. 200 anos do sistema brasileiro de patentes: o Alvará de 28 de abril de 1809 - comércio, técnica e vida. Rio de Janeiro: Lumen Júris, 2009.

CERQUEIRA, J.G. Tratado da Propriedade Industrial. 2 ed., rev. e atual. por Luiz Gonzaga do Rio Verde e João Casimiro Costa Neto. São Paulo: Revista dos Tribunais, 1982.

CRUZ, H; TAVARES, M. As Patentes Brasileiras de 1830 a 1891. Estudos Econômicos, v. 16, n. 2, p. 205-25, 1986. 
CRUZ FILHO. M.F. A entrada do Brasil na Convenção Internacional para a Proteção da Propriedade Industrial. Paris, 1883. Rio de Janeiro: INPI, 1982.

CRUZ FILHO. M.F. A norma do novo: fundamentos do sistema de patentes na modernidade. 3 ed. rev. Rio de Janeiro: [s.n.], 2015. Disponível em: https://sites.google.com/site/murillocruzfilho/principais-ensaios/norma. Acesso em: 06 jun. 2020.

CRUZ FILHO, M.F. Bartolomeu Lourenço de Gusmão: sua obra e o significado fáustico de sua vida. Rio de Janeiro: Biblioteca Reprográfica Xerox, 1985.

DI BLASI, G.; GARCIA, M.S.; MENDES, P.P. A propriedade Industrial. Rio de Janeiro: Forense, 1998.

DOMINGUES, D.G. Marcas e expressões de propaganda. Rio de Janeiro: Forense, 1984.

EXAME prévio das invenções. Jornal do Commercio, Rio de Janeiro, ano 97, n. 357, p. 2, 28 dez. 1923.

EXPOSIÇÃO de motivos apresentada pelo Sr. Ministro da Agricultura. Jornal do Commercio, Rio de Janeiro, ano 97, n. 352, p. 4, 22 dez. 1923.

FRANCO, G.H.B. A primeira década republicana. In: ABREU, M.P. (org.). A ordem do progresso: cem anos de política econômica republicana, 1889-1989. Rio de Janeiro: Campus, 1989, p. 11-30.

FRANCO, G.H.B.; LAGO, L.A.C. O processo econômico. In: SCHWARCZ, L. (coord.). A abertura para o mundo, 1889-1930. Rio de Janeiro: Objetiva; Madrid: Fundación Mapfre, 2012, p. 173-238. (Coleção História do Brasil Nação: 1808-2010, Volume 3).

FRITSCH, W. Apogeu e crise da Primeira República. In: A ordem do progresso: cem anos de política econômica republicana, 1889-1989. Rio de Janeiro: Campus, 1989, p.31-72.

GALVÃO, L.M. Espaços de construção da interpretação constitucional: análise dos congressos jurídicos da Primeira República. Revista Jurídica da Presidência, Brasília, v. 19, n. 118, p. 377-401, jun./set. 2017.

LOPREATO, C. O espírito da revolta: a greve geral anarquista de 1917. São Paulo: Annablume/Fapesp, 2000. 
LUZ, N.V. A luta pela industrialização do Brasil. São Paulo: Alfa-Ômega, 1975.

MALAVOTA, L.M. A construção do sistema de patentes no Brasil: um olhar histórico. Rio de Janeiro Lumen Juris, 2011.

MALAVOTA, L.M. A Sociedade Auxiliadora da Indústria Nacional e as patentes de invenção: tecnologia e propriedade no Império do Brasil. Revista Maracanan, Rio de Janeiro, n. 23, p. 12-33, jan./abr. 2020. Disponível em: https://www.epublicacoes.uerj.br/index.php/maracanan/article/view/45211. Acesso em: 08 abr. 2021.

MARTINS, M.F. A velha arte de governar: um estudo sobre política e elites a partir do Conselho de Estado (1842-1889). Rio de Janeiro: Arquivo Nacional, 2007.

MARINHO, A.G. A invenção como parte do processo de industrialização: patentes inglesas no Brasil (1882-1910). In: CONGRESSO BRASILEIRO DE HISTÓRIA ECONÔMICA, 12, 2017, Niterói. Anais... Niterói: ABPHE, 2017. Disponível em:

http://www.abphe.org.br/uploads/ABPHE\%202017/7\%20A\%20inven\%C3\%A7\%C 3\%A3o $\% 20$ como $\% 20$ parte $\% 20$ do $\% 20$ processo $\% 20$ de $\% 20$ industrializa $\%$ C3\%A7\%C 3\%A3o\%20patentes\%20inglesas\%20no\%20Brasil\%20(1882-1910).pdf. Acesso em: 15 maio 2020.

O MINISTÉRIO do Trabalho, Indústria e Comércio e a sua função na economia brasileira. Exposição que acompanha o relatório apresentado ao Senhor Presidente da República Doutor Getúlio Vargas pelo ministro Agamemnon Magalhães. Rio de Janeiro: [s.n.], 1936.

PÓVOA, L.C.; CABELLO, A. Análise econômica da primeira Lei de Patentes brasileira. Brasília: Núcleo de Estudos e Pesquisas/CONLEG/Senado, mar. 2016. (Textos para Discussão, 192). Disponível em:

https://www12.senado.leg.br/publicacoes/estudos-legislativos/tipos-deestudos/textos-para-discussao/TD192. Acesso em 06 jun. 2020.

PROJETO de lei para privilégios de invenção no Império do Brasil. O Auxiliador da Indústria Nacional, ano XLII, n.5, p. 201-21, mai. 1874.

PROPRIEDADE industrial. Jornal do Commercio, Rio de Janeiro, ano 97, n. 121, p. 8, 4 maio 1923.

RELATÓRIO apresentado à Assembleia Geral na primeira sessão da décima oitava legislatura pelo Ministro e Secretário de Estado interino dos Negócios da 
Agricultura, Commercio e Obras Públicas José Antônio Saraiva. Rio de Janeiro: Typographia Nacional, 1882.

RELATÓRIO apresentado ao Presidente da República dos Estados Unidos do Brasil pelo Ministro de Estado dos Negócios da Agricultura, Comércio e Obras Públicas, Barão de Lucena, em junho de 1891. Rio de Janeiro: Imprensa Nacional, 1891.

RELATÓRIO apresentado ao Vice-Presidente da República dos Estados Unidos do Brasil pelo Ministro de Estado dos Negócios da Agricultura, Comércio e Obras Públicas, Engenheiro Antão Gonçalves de Faria em maio de 1892. Rio de Janeiro: Imprensa Nacional, 1892.

RELATÓRIO apresentado ao Presidente da República dos Estados Unidos do Brasil pelo Ministro de Estado dos Negócios da Agricultura, Indústria e Comércio, Dr. Pedro de Toledo, no anno de 1911. V.1. Rio de Janeiro: Imprensa Nacional, 1911.

RELATÓRIO apresentado ao Presidente da República dos Estados Unidos do

Brasil pelo Ministro de Estado dos Negócios da Agricultura, Indústria e Comércio, Geminiano Lyra Castro, no anno de 1926. Rio de Janeiro: Imprensa Nacional, 1928a.

RELATÓRIO apresentado ao Presidente da República dos Estados Unidos do Brasil pelo Ministro de Estado dos Negócios da Agricultura, Indústria e Comércio, Geminiano Lyra Castro, no anno de 1928. Rio de Janeiro: Typographia do Serviço de Informações do Ministério da Agricultura: 1929.

RELATÓRIO apresentado ao Presidente da República dos Estados Unidos do Brasil pelo Ministro de Estado dos Negócios da Agricultura, Indústria e Comércio, Geminiano Lyra Castro, no anno de 1929. Rio de Janeiro: Typographia do Serviço de Informações do Ministério da Agricultura, 1930.

RELATÓRIO apresentado ao Presidente da República dos Estados Unidos do Brasil pelo Ministro de Estado dos Negócios da Agricultura, Indústria e Comércio, Miguel Calmon Du Pin e Almeida no anno de 1924. Rio de Janeiro: Imprensa Nacional, 1928b.

RELATÓRIO apresentado ao Presidente da República dos Estados Unidos do Brasil pelo Ministro de Estado dos negócios da Indústria, Viação e Obras Públicas, Severino dos Santos Vieira, no ano de 1899. Rio de Janeiro: Imprensa Nacional, 1899. 
RELATÓRIO apresentado ao Presidente da República dos Estados Unidos do Brasil pelo Ministro de Estado dos Negócios da Indústria, Viação e Obras Públicas, Antônio Olinto dos Santos Pires em maio de 1896. Rio de Janeiro: Imprensa Nacional, 1896.

REMODELA-SE o nosso direito industrial. A Noite, ano 13, n. 4.341, p. 1, 28 dez. 1923.

RODRIGUES, C.C. A inventiva brasileira. 2v. Brasília: MEC/INL, 1973.

RODRIGUES, J.H. O Conselho de Estado: o quinto poder? Brasília: Senado Federal, 1978.

SANTANA, F. Aspectos de inovação na indústria portuguesa durante a segunda metade do século XVIII e primeiro terço do século XIX. In: Anais da Academia Portuguesa de História. II Série. V. 29. Lisboa: Academia Portuguesa de História, 1984, p. 233-310.

SILVA, J.L.W. Isto é o que me parece: a Sociedade Auxiliadora da Indústria Nacional (1827-1904) na formação social brasileira. 1979. 2 v. Dissertação (Mestrado em História) - Instituto de Ciências Humanas e Filosofia, Universidade Federal Fluminense, Niterói, 1979.

SPINDEL, C.R. Homens e máquinas na transição de uma economia cafeeira. Rio de Janeiro: Paz e Terra, 1979.

SUZIGAN, W., SZMERECSÁNYI, T. Os investimentos estrangeiros no início da industrialização do Brasil. In: SILVA, S.S.; SZMERECSÁNYI, T. História econômica da Primeira República. 2 ed. rev. São Paulo: Hucitec/ABPHE/Edusp/Imprensa Oficial, 2002, p. 261-83.

UNION INTERNATIONALE POUR LA PROTECTION DE LA PROPRIETE INDUSTRIELLE. Actes de la Conference reunis à Bruxelles du $1^{\text {er }}$ au 14 decembre de 1897 et du 11 au 14 decembre de 1900. Berne: Bureau International de l'Union, 1901.

WORLD INTELLECTUAL PROPERTY ORGANIZATION (WIPO). What is intelectual property? Geneve: OMPI, 2004. Disponível em https:/www.wipo.int/edocs/pubdocs/en/intproperty/450/wipo_pub_450.pdf. Acesso em: 05 jun. 2020. 